\title{
ASTRONOMY, ARCHITECTURE AND SYMBOLISM: THE GLOBAL PROJECT OF SNEFERU AT DAHSHUR
}

\author{
JUAN ANTONIO BELMONTE, Instituto de Astrofísica de Canarias \& Universidad de Laguna, and \\ GIULIO MAGLI, Politecnico di Milano
}

To be Published in Journal for the History of Astronomy 46, 3 (2105)

\begin{abstract}
The two pyramids built during the Old Kingdom by the 4th Dynasty King Sneferu at Dahshur are usually considered as two consecutive projects, the second - that of the Red Pyramid - being generated by a presumably failure of the first, the Bent Pyramid. In the present paper we show that the archaeological proofs of such a scenario are far from obvious and that, on the contrary, a series of architectural, topographical, epigraphic and astronomical hints point to a unitary project probably conceived from the very beginning in terms of the two pyramids and their annexes. The two pyramids all-together are thus shown to form a conceptual, sacred landscape associated with the power of the Pharaoh and his afterlife.
\end{abstract}

\section{Key words}

Archaeoastronomy, orientations, pyramid architecture, Dahshur, Sneferu, Pyramid Texts, Egyptian symbolism

If you doubt our might, look at our buildings

Ryszard Kapuściński, 1993

Since first proposed by Ahmed Fakhry, ${ }^{1}$ it has been accepted as a fact, almost like a dogma by generations of Egyptologists, that during the reign of Pharaoh Sneferu (c. 2575 B.C.) there was an evolutionary process of trial and error in the construction of pyramids. Acccording to this hypothesis, the so-called Bent Pyramid in Dahshur ( $\left.h^{c}-s n f r w-r s y\right)$ would be a perfect example of a process that finally led to the first 'perfect' pyramid, the so-called Red Pyramid ( $h^{\complement}$-snfrw), built in the same place by the King perhaps a decade or so later. However, recent ideas enthusiastically defended by the second author and based on architectural criteria, postulate that the two pyramids of Sneferu at Dahshur actually form a single project conceived as such since its inception. ${ }^{2}$

Given this suggestive possibility, the authors decided to undertake a detailed study of the information available, both from a chronological and an epigraphic point of view - a new reading of the Palermo stone and a new analysis of the Pyramids Texts. Astronomy will play a most determinant role in the creation of new ideas - among these being a reasonable explanation of why the anomalous slope of $43^{\circ} 40^{\prime}$ for the Red Pyramid -, which apparently will support the hypothesis that the two great pyramids of Sneferu at Dahshur were conceived as a unitary project. At such a singular site, astronomy and architecture combined to produce a tangible reality charged with symbolism on a truly gigantic scale. This possibility might further support the idea that the two great pyramids of Giza would also have formed a singular unitary project in a still larger scale during the reign of Sneferu's son, Khufu (c. 2550 B.C.): The 'Horizon of Cheops' or 3ht hwfw.

The leitmotif of the ideas defended in this paper is the independent research on the topic performed by the two authors, who, starting from different approaches - symbolism and architectural design, with a common interest in a cultural astronomy approach - were able to reach to the identical conclusion that the pair of gigantic pyramids at Dahshur were finished, and even perhaps conceived, as a unique project where, apart from the strongly symbolic aspect and the obligation of accomplishing king's needs for the hereafter, Sneferu was able to demonstrate his dominion over all the land by the mere contemplation of his monuments. ${ }^{3}$

\section{INTRODUCTION}

The pyramids probably are the most impressive human manipulation of the natural landscape. King Sneferu (c. 2575 B.C. $)^{4}$ stands out as one of the greatest builders in human history, not only in terms of the sheer volume of his architectural feats (the largest ever accomplished by any king of Egypt), but also in 
terms of innovation. It was in fact during Sneferu's reign that step pyramids, built from the outset of the 3rd Dynasty during the reign of Netjerkhet, were optimized and later abandoned in favour of geometrical pyramids, and interior chambers and corridors were first constructed in the body of these monuments. All this occurred during a long reign of at least three decades (with the year of the 24th occasion [of the cattle count], as his highest possible date), ${ }^{5}$ with the construction of as many as three gigantic and not less than three (perhaps as many as nine) lesser pyramids.

In the first years of his reign, Sneferu built a large pyramid in the size of a huge eight-step monument (in its 'final' design) at Meidum, and another smaller step pyramid nearby at Seila, on the hills to the west. Seila is plainly visible from Meidum, but visually dominates a large area of the Fayoum, from where Meidum is not visible. This is the only minor step pyramid whose affiliation has been established beyond doubt. The minor step pyramids (MSPs) form a coherent group of seven (perhaps eight) monuments distributed along Egyptian geography and sharing a series of common characteristics that make them different from and peculiar to other buildings of similar typology. Like the other MSPs, Seila has no interior chamber, so its aim was perhaps purely symbolic. The purpose of these pyramids is a matter of dispute among Egyptologists and most proposals could be interpreted as sad examples of vox nihil, although it has reasonably been suggested that they were built by King Sneferu with the clear intention of demonstrating his royal power. ${ }^{6}$ An archaeoastronomical study of the monuments would furthermore suggest that minor step pyramids were built at certain locations and with peculiar orientations possibly relating them to the preliminary stages and consolidation, during the reign of Sneferu, of two master creations of early dynastic Egypt, the civil calendar and the stellar eschatology later appearing in the Pyramid Texts. ${ }^{7}$ These two intellectual master pieces of Egyptian ingenuity will be most relevant in the following discussion.

For some hitherto unknown reason, when he was nearly a decade on the throne Sneferu changed the expected site of his burial at Meidum, where several members of his family, including at least a couple of siblings had already been interred in monumental mastabas. He then ordered the construction of a set of completely new monuments at Dahshur, including snfrw, the so-called Bent and Red Pyramids, respectively (see Table 1). As already mentioned, these two pyramids are usually considered in the existing literature as two consecutive projects; that is to say, it is believed that the Red Pyramid was constructed for functional reasons because the Bent one, built first, was abandoned as a burial site, being considered unsafe owing to the risk of collapse. It is the aim of the present paper to discuss an impressive series of clues that cast serious doubt on this theory, and lead us rather to think that the two monuments were conceived together as parts of a global project that fulfilled a series of symbolic, rather than merely functional aims.

\section{DISCUSSION: PRESENTATION AND ANALYSIS OF THE DATA}

That the two pyramids of Sneferu at Dahshur could have been the result of a unified project is not a new idea. ${ }^{8}$ Earlier Egyptologists who had dealt with Dahshur doubted that the Bent pyramid was built by Sneferu simply because it was finished complete with casing stones, enclosure wall, subsidiary or satellite pyramid, and both a valley and pyramid temples. Actually, most citations of $h^{\top}$-snfrw-rsy were thought to refer to the pyramid of Meidum which certainly was to the 'south' ( $r s y$ ) of Dahshur.' It was only after Fakhry's work on site and the clear adscription of the Bent pyramid to Sneferu that the story of the 'fake' or 'failed' pyramid polluted Egyptological literature.

The authors are perfectly aware that it is extremely difficult to fight against a well-established academic dogma but, as we hope to show the clues for a single monumental project at Dahshur in Sneferu's reign are overwhelming. The analysis will be done following various approaches and shows the evolution of the research process. First, the rough monumental data will be presented; then we will deal with those facts of the buildings' architecture supporting a single project. Later on, topography and epigraphy (including evidence from the Palermo Stone and the Pyramid Texts) ${ }^{10}$ will be considered. Finally, certain important astronomical facts, concomitant with the epoch of Sneferu will be analysed and joined with previous arguments to offer a clear-cut picture for a change of paradigm.

\subsection{The pyramids of Sneferu at Dahshur: architectural facts}

Dahshur is a desert plateau located about seven kilometres to the south of Saqqara, the central necropolis of Memphis, capital of Egypt during the Old Kingdom (see Figure 1). Here stand the two pyramids of Sneferu, the southernmost one which displays a softening in its inclination and is therefore usually called the Bent Pyramid, and the northern one, located some 1800 metres to the north and called 
the Red Pyramid because of the deep reddish hue of its limestone blocks locally quarried from a special vein of limestone peculiar to the site (see Figure 2).

The Bent Pyramid is 189 metres wide and 105 metres tall. It is still cased with huge limestone blocks arranged on inclined beds. This monument marks a technical and architectural breakthrough with respect to the previously built step pyramids. Firstly, the dimensions and the weight of the stone blocks become much greater, almost megalithic. Secondly, the construction technique is new. During the 3rd Dynasty the building strategy was based on setting 'layers' of rectangular casing with an inward slope. The result was that these early pyramids were made by 'accretions' surrounding a central core, with no functional distinction between casing and external layer at the exterior. With the Bent Pyramid of Sneferu the architects successfully experiment with a completely new idea: to build the pyramid on the basis of a core of huge stones settled on progressive horizontal courses. ${ }^{11}$ In this way, each course can be completed in a single stage, the architect having tight control over dimension, alignment, angles and suchlike at each successive constructional step.

The task of making the pyramid a geometrical, true flat-face pyramid demanded another new idea: the use of casing blocks. This had several advantages, including the possibility of using high-quality, whitish limestone unavailable on site but transported from the opposite bank of the Nile. There are clearly two possibilities for obtaining the chosen slope of the exterior face: one is to cut originally rectangular casing blocks on one face, and then set the squared part of the blocks on the pre-existing horizontal layers; the other is to put in place rectangular or almost rectangular blocks, but on inclined beds. This second possibility is technically more difficult than the first, but clearly assures a much more resistant structure. Given the very high slope chosen for the lower part of the Bent Pyramid, the builders opted for this solution. Interestingly enough, besides giving strength and solidity to the building, this way of encasing a pyramid is also much more difficult to dismantle than the other. As a consequence, the Bent Pyramid is the unique one still to be almost entirely cased because it survived attempts to dismantle the casing blocks made mostly in the Roman period and the Middle Ages. The stone robbers apparently started from the corners, and indeed the corners are the only parts that appear completely dismantled, giving us a glimpse of the incredible skills of Sneferu's master masons. All these facts are illustrated in Figure 3.

The slope of the pyramid changes at a height of 49 metres, with the initial inclination dropping by more than $10^{\circ}$ (see Table 1). The pyramid is unique also because it has two distinct internal apartments, which were designed and built independently and were only connected by a narrow secondary passage way. The entrances to these structures were located on the north and west faces of the pyramid, respectively. The north apartment consists of a descending passage leading to a first corbelled chamber. From here, the inner chamber - located at a greater height and also corbelled - can be accessed. A side room contains a vertical shaft of unknown purpose located precisely under the apex of the pyramid. The west chamber is accessed from a descending passage open in the west side of the pyramid which, after levelling off to the horizontal, was blocked by a portcullis system of two sliding slabs. The chamber is at a higher level than the first; when excavated, it was found partly filled by a masonry and wooden structure, of which some original cedar logs remain in place. Quarry marks with Sneferu cartouches, traced in red ink, were found on the blocks, but without further indications. ${ }^{12}$

The complex of the Bent Pyramid includes a small upper temple (chapel) to the east of the pyramid (see Fig. 3), a causeway and a 'Valley' Temple. The Valley Temple is a rectangular stone building, with an open courtyard and a gallery that probably originally accommodated six statues of the King. Of the causeway, only the foundations remain. To the south of the Bent Pyramid, and on the same axis, we find the so-called satellite or subsidiary, another pyramid some thirty metres high with a slope of

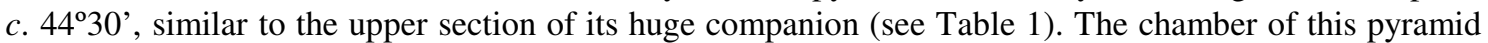
is too small for a human burial, and was probably meant for the burial of a statue designated to house the $\mathrm{Ka}$, the 'vital spirit' of the deceased King. We will later come back to this curious monument when analysing the orientation of its access corridor located close to ground level in its northern face (Fig. 3).

The north pyramid of Dahshur or Red Pyramid is a little larger at the base compared to its sister to the south, but its height is virtually identical because the chosen slope was lower and equal to that of the upper part of the south pyramid, a first and most substantial hint as to the wish of the builders to transmit a unified message (see Table 1). Quarry marks have been found on some of its blocks, dated to the 15th 'tenet'(or 'occasion') ${ }^{13}$ at the base (year 19 or 20 approximately), and to later years at higher levels. ${ }^{14}$ The substructure of the pyramid is arranged as follows. The descending corridor, which opens to the north, arrives at ground level, where two almost identical spectacular chambers with high corbelled roofs are aligned north to south and connected by a short horizontal passage. In the south wall of the second chamber, accessed by a staircase, another corridor leads to the final chamber, which is built within the masonry of the pyramid and orientated east-west. The reason for the room being at a higher level compared to the antechamber was probably structural, because the corbelled roof of the last chamber 
would have exerted its pull on the relatively thin layer of masonry located in front of the corbelled roof of the antechamber. ${ }^{15}$

The annexes of the Red Pyramid consist of a chapel, or small funerary temple, located to the east. In the centre of the ruins of this former sanctuary, archaeologists have placed the capstone of the pyramid which has been recovered in pieces nearby and reconstructed (see Fig. 2). The slope of this pyramidion is the same of the lower part of the Bent Pyramid (see Table 1), so that, once again, the two monuments had a sort of alternate, specular slopes. A causeway presumably ran due east from the temple but has never been excavated; its projected course would have crossed the building of the modern ticket office, under which a 'valley' temple may have been projected.

\subsection{Architectural hints to a global project of Sneferu.}

If the Bent Pyramid had been finished with a constant slope, the curious idea that it is an example of an imperfect pyramid would almost certainly not have plagued Egyptological literature for more than half a century. Instead, the abrupt change in inclination led different scholars to propose that the slope was reduced drastically in order to reduce the weight, because of the risk of collapse. ${ }^{16}$ The proofs of such alleged 'collapse danger' are, however, difficult to substantiate. The monument is indeed perfectly safe and accessible in all its interior parts, there are no visible cracks in the roofs or on the ceilings and the casing is fairly intact (small patches inserted here and there probably refer to a restoration carried out to Old Kingdom monuments during the New Kingdom). Further, the visible courses of stones show no signs of rupture, apart from some cracked blocks at one of the corners.

So what proof is there of a real danger of collapse? Actually in the two descending corridors of the pyramid a fracture can be seen; in correspondence of the fracture, an impressive (more than $10 \mathrm{~cm}$ ) displacement is recognizable within the corridors. As mentioned the two corridors start on the north and west faces respectively at different heights and run at different angles (see Table 1). However, if a N-S section of the pyramid, superimposed on an E-W section, are plotted, it can be seen that the fractures are located along an inclined line that is more or less parallel to the pyramid face.

This led Maragioglio and Rinaldi, in the early 1960s, ${ }^{17}$ to draw the conclusion that a unique, huge movement of the exterior mantel of blocks occurred in the pyramid (noting a continuous joint at one of the fractures they also proposed the existence of a 'primitive', more inclined $-c .60^{\circ}$ slope - pyramid inside the structure, a theory that remains untested and unproven; rather, the presence of the continuous joint made the corresponding point more fragile). So the commonly accepted idea is that it was this displacement what scared the builders and led them to the change of slope. This is, however, quite debatable. First of all, it is impossible to assign a date to the displacement, so there is no proof that it occurred during construction. Further, the most likely reason for the problem is not in the construction features but in an earthquake and this shortens even more the odds that the event occurred at Sneferu's times. Finally, the monument settled in a safe equilibrium state, the same as it is today. So, even if the displacement occurred during construction, the stability of the pyramid could have seemed reasonable, although it could have been perceived differently by Sneferu's architects. A side issue exists; namely, the already mentioned presence of a stone and wood scaffolding in the upper chamber, found (and unfortunately hastily removed) during Fakhry's excavation. ${ }^{18}$ The function of this structure is not at all clear but it is certainly not an emergency structure built to ensure the resistance of the western apartment, since no fractures exist in the room itself.

To sum up, the architectural evidence for a change of project - from the Bent to the Red - is very poor. In contrast, as we shall see, there are many hints of a global project. To start investigating what might have been the nature and the motivations for such a project, we start from the duality apparent in the site - two enormous pyramids of equal height, two funerary apartments in the south pyramid, two complexes of annexes within the Valley Temple of the 'abandoned' Bent Pyramid, showing no signs of having been left unfinished or non-functioning, but just the contrary. Moreover, as mentioned above, a near mirror symmetry was in play in the slopes - a crucial hint as will be discussed afterwards -. A unique and real asymmetry is the absence of a satellite of the north pyramid; of course, this is a further hint at a global project, since the Red Pyramid would possibly have needed its own satellite if the machinery of the King's burial and rebirth had been fully transferred to the northern complex.

Duality in the funerary cult is hardly a novelty - a striking example is Netjerkhet's complex at Saqqara, with two tombs and a continual, almost obsessive reference to 'the two lands' - . The pairing of the tombs may actually represent a tribute to the tradition of the Pharaoh as the ruler of unified Upper and Lower Egypt, although the change in the slope of the Bent Pyramid - which perhaps was planned from the very beginning as various hints will show - has remained in itself something of a mystery, being a one-off solution never to be adopted again in the history of Egyptian pyramids. The existence of the west corridor 
and chamber is also unique: the sole possible resemblance being that Netjerkhet's 'South Tomb' had the same pattern of orientation. ${ }^{19}$

\subsection{Dahshur's topography: a built landscape}

Let us accept for a moment the idea of a global Sneferu project. Was the choice of the Dahshur plateau dictated by, and only by, practical reasons? The answer under the premise of a unified project is probably in the negative. In fact, as it happens, there is a very clear topographical and visual link between the Sneferu pyramids and the Saqqara plateau to the north. Indeed, when viewed from Saqqara, the Sneferu pyramids form an artificial, symbolic horizon of two paired mountains:

a $\underline{d} w$ sign (see Fig. 2). ${ }^{20}$ There are few natural mountains in the Nile valley. Most of the orographic elements are the bluffs of desert ridges, crossed by seasonal water streams or wadis. In fact this is probably the origin of this sign, which is extremely ancient, as it appears already in the seals found in the pre-dynastic tomb U-j at Umm el Qab, the Abydos necropolis, where a 'King Elephant mountain' is mentioned. ${ }^{21}$ Its connection with afterlife and with Abydos in particular is clear. To the southern horizon of the necropolis a huge wadi opens into the Umm el-Qab bay, functioning as a sort of 'mouth of the afterworld'. The sign appears explicitly in the name of Abydos, which was:

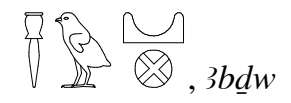

and in curious ritual objects (today called Osiris' reliquary) associated with the Abydos sacred centre. Actually, the idea of a 'sign of two mountains' will later be present in several royal funerary landscapes of ancient Egypt, ${ }^{22}$ and will appear explicitly in funerary texts; for instance, in the Book of the Gates, the Duat is entered from a gate located between a double 'mountain of the west'.

Thus the pyramids of Sneferu perhaps played the role of a symbolic $\underline{d} w$ located to the south of the Saqqara necropolis. ${ }^{23}$ The effect is particularly striking when the site is seen from the Saqqara plateau; that is, from the revered necropolis of the kings of the two previous dynasties. The paired 'mountains' of Sneferu are clearly seen by any visitor approaching the plateau along the ancient pathway from Memphis, which ran along a wadi located a few hundred metres to the north of the Step Pyramid, and who approached the Step Pyramid complex along its sides. This heady experience can still be enjoyed today, especially on clear days, and is enhanced by the sight of the later monument constructed by Shepsekaf, last king of Sneferu's dynasty, who placed his tomb precisely along the line that starts at the horizon in between the two pyramids at Dahshur and crosses the Saqqara central field at the ancient 'entrance' area located near the Teti pyramid. ${ }^{24}$ The whole complex transmit a 'sense of geometrical order' - what the Egyptians would call Ma'at - to the point that much later, Middle Kingdom projects built in the same area will try to conform strictly to parallel topographic rules. ${ }^{25}$

We might assert, then, that it is with the dual unique project of Sneferu at Dahshur that we begin to perceive an increasing symbolic value of the pyramids: it is with this king that the pyramids became actual 'gigantic hieroglyphs', as Mark Lehner has written. ${ }^{26}$ The very idea of creation was tied up with writing in the Egyptians' mind; ${ }^{27}$ thus in a sense the couple of pyramids becomes a 'sign' within a 'written' landscape.

\subsection{Epigraphical hints: names and texts}

From Sneferu onwards, if not earlier, ${ }^{28}$ each royal pyramid complex received a name, which in several cases has been passed on to us in the reliefs of the tombs of the officials and priests in charge of the complexes. The pyramid of Meidum was the first certainly to receive such a name: Djed Sneferu, 'Sneferu endures'. ${ }^{29}$ On the one hand, the Red Pyramid was called $1 t^{*} \leq \Delta$. The name is made up of Sneferu's name as Egyptian Double-King (inscribed in a cartouche), the hieroglyph $\bullet-h^{c}$, and the pyramid determinative and should be read as $h^{\top}$ - snfrw, or Kha-Sneferu, which is usually translated as 'Sneferu shines'or 'Sneferu is bright'. However, the verbal stem $h^{\ulcorner}$describes both the rising (and hence the first bright appearance) of a celestial object and the king's assumption of royal regalia, notably of the crowns, as well as his ritual appearances in festival and processions. ${ }^{30}$ This is nicely illustrated by the title: 


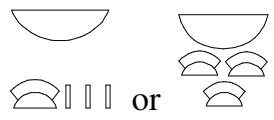

$n b h^{\complement} w$, Neb-khau ('Lord of the Crowns') often assigned to the Double-King in his tittles. Hence, the term $h^{\top}$ may come to denote crown, as well as 'form of appearance' or 'manifestations' a fact which could be particularly significant in the context of celestial ascent and transfiguration of the king after his death within the context of the sky eschatology as presented in the Pyramid Texts of the Old Kingdom. ${ }^{31}$ As a matter of fact, the name of the Red Pyramid could then be also translated as 'Sneferu manifests himself' (by the wearing of the crown) or, in alternative reading, as literally, the 'Crown of Sneferu' in a parallel to the reading of his son's pyramid complex name, Akhet Khufu, as the 'Horizon of Cheops' (see below).

On the other hand, the ancient name of the Bent Pyramid was the same as that of the Red Pyramid: $\triangle \Delta$, but with the addition of a sign denoting 'south' or also 'Upper Egypt'. This would be read as $h^{\complement}$-snfrw-rsy, and has been conventionally translated as 'Sneferu shines in the south'. However, considering the previous discussion, the name of the Bent Pyramid could be translated as 'Sneferu appears (wearing the crown) in the south' or, in an alternative reading, the 'Southern Crown of Sneferu'.

The complementarity of the names of the two pyramids is certainly a further hint of a common project. Actually, if we seek further support, we might note that Sneferu's mortuary complex was referred to, in a decree issued by 6th Dynasty King Pepi I (c. 2250 B.C.) regulating the administration of the pyramid town in Dahshur, found on an inscribed stone not far from the Red Pyramid, ${ }^{32}$ as:

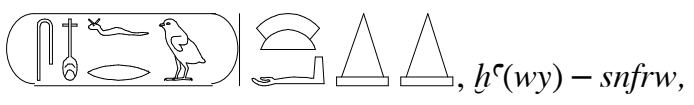

which could be translated either as 'The two pyramids - Sneferu shines', or perhaps, even better as 'The two pyramids: the crown(s) of Sneferu'. A much lesser known fact is that the complex had already been referred in this way in much earlier times, since in the false door of the tomb of a high priest of the Sneferu cult called Dware, who lived in the early 5th Dynasty - less than one hundred years after Sneferu - we learn that his main title was 'Overseer of $0 t^{2}-\Delta \Delta \Delta$ ', suggesting that this might have been a name of the 'complete' complex of Dahshur from the very beginning. ${ }^{33}$

With these new clues and considerations, it is now time to analyse the most suggestive epigraphic hint for a unique project. This is contained in the so-called Palermo Stone - the annals of the kings of the first five dynasties $-{ }^{34}$ and is illustrated in Figure 4. It is actually in the Palermo stone where the use of the term $\_-h^{r}$ is clearly first attested to designate the assumption of crowns by the terrestrial ruler. $^{35}$ The readable passages of the Palermo Stone about Sneferu's reign (see Fig. 4) contain two curious references.

On the one hand, in the year before the 7th occasion (presumably regnal year 8/9), there is the following sentence nearly at the end of the conspicuous facts defining that year: $k d$ inb rsy $t 3-m h w$ hwwtsnfrw. This sentence has often being translated as 'the construction of the wall of the South (or Upper Egypt) and the North[land]: the Mansions of Sneferu'. This building, or buildings, is sometimes associated with the construction of fortresses somewhere within the borders of the country. ${ }^{36}$ However, the authors are of the opinion that this entry would much better fit with the beginning of the construction of a new palatial complex in the area of Dahshur - at the edge of the northern and southern parts of the country - where the court would now be moved. In year 8/9, the 8-step pyramid 'Sneferu endures' at Meidum should have been nearly finished. However, this necropolis was abandoned and a new one inaugurated at Dahshur, for unknown reasons (perhaps the two nearly successive deaths of two crownprinces, Neferma' at and Kanefer, both buried at Meidum).

This could be related, on the other hand, with a second entry in the Palermo Stone (see Fig. 4) corresponding to the year of the 8th $t h t$, two years after the previous cite (i.e. year 10/11). Here the text

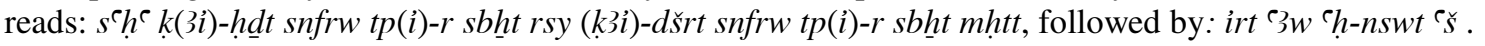
The latter sentence mentions the fabrication of the wood doors for the palace of the king, which could perhaps be the same building started in year $8 / 9$. However, much more important is the former sentence which could be read as: 'Erecting "Sneferu is exalted with the White Crown" upon the Gate of the South [and erecting] Sneferu [is exalted] with the Red Crown" upon the Gate of the North'. Once more, in the literature these buildings are usually identified with each other (as a single palace with two gates) or interpreted as fortifications at the boundaries of the country, but in any case they are assumed to be, archaeologically speaking, completely unknown. ${ }^{37}$ 
So, we can summarize what the Palermo stone apparently tells us here about Sneferu's buildings as follows: there should be - actually somewhere in Egypt or in its frontiers - a couple of buildings conceived, planned and perhaps started to be built together, celebrating Sneferu as Double-King, and sovereign of the two lands, one associated with the Red Crown of the north, the other with the White Crown of the south, of which we have no trace, but which are so important as to be mentioned in the Royal Annals, where, on the other hand, the huge pyramids built by the same king are not mentioned (at least in the few preserved sections of the annals). However, if we could read 'gate' as 'limit' (not an impossible reading) or even 'frontier' and we take a quick glance at the map in Figure 1, a fascinating, appealing and suggestive hypothesis arises: the two buildings mentioned could be the two gigantic pyramids of Sneferu at Dahshur, whose complex planning and construction started on site two years after the beginning of the royal palace for which the doors were made in the same year, suggesting that the court was already moving to Dahshur at the 'limits' between the North and the South (Fig. 1). ${ }^{38}$ This would not be in conflict with the fact that the superstructure of the Red Pyramid and important parts of the Valley temple were started a few years later as shown by mason marks. ${ }^{39}$

Furthermore, a clear symbolism can be discerned. On the one hand, Sneferu's northern pyramid would have been built close to a deposit of reddish limestone that was used to build the core of the flatter 'Red' pyramid, thus symbolizing his status as wearer of the nearly flat Red Crown of Lower Egypt. ${ }^{40}$ On the other hand, the 'Bent' pyramid, built with common white limestone, has a white core and was built on the southern end of the pyramid dual complex, symbolizing Sneferu's status as wearer of the conicalshaped White Crown of Upper Egypt. ${ }^{41}$ This is nicely illustrated in Figure 5. This would be in perfect agreement with the alternative names of the pyramids as 'Sneferu's Crown' and 'Sneferu's Crown of the South', respectively, and would further suggest that the pyramids could actually be seen as gigantic symbolic representation of the two most important manifestations of power of the Pharaoh as King of Lower and Upper Egypt, namely the Red and White Crowns, respectively. There is further evidence supporting this assumption and the hypothesis of a unique dual project being developed at Dahshur, but to go further into the discussion, a new section must be opened.

\subsection{Astronomical hints: orientations, slopes and calendar}

For the ancient Egyptians, the astronomical orientation of their sacred monuments was a central intrinsic value of their need for Cosmic Order. ${ }^{42}$ In this sense, it is well-known that the plan of the vast majority of the ancient Egyptian pyramids is such that most of these monuments are orientated according to the cardinal points and in several cases with astonishing precision such as that reached in the two larger pyramids of Giza. The question how such huge structures could have been orientated with such precision still attracts the attention of many scholars, and many interesting ideas have been proposed in recent years, the most compelling being those based on stellar alignments which are based on Egyptian procedures such as the 'stretching of the cord' ceremony, ${ }^{43}$ and the orientation to conspicuous Egyptian constellations mentioned in the Pyramid Texts as distinct members of the ihmw skw, the 'imperishable stars', such as Meskhetyu (see Figure 6). ${ }^{44}$

As shown in Table 1, the pyramids of Sneferu at Dahshur were also nicely oriented to the north with quite accurate precision. Although there is evidence of the use of the 'stretching of the cord' ceremony in earlier dynasties - namely, in the Palermo Stone -, one of the first images of the ceremony located in situ was precisely found in fragments in the Valley temple of the Bent Pyramid (see Fig. 6), thus suggesting that the different buildings of Sneferu's complex at Dahshur were aligned following this procedure. A northern alignment would possibly seek the flight of the soul of the king, his $b$, towards the imperishable stars, orbiting the northern celestial pole, through the ascending northern corridor of the pyramid, as it was later reflected in the Pyramid Texts. ${ }^{45}$

The discussion on the possible astronomical orientation of the ascending corridors of the pyramids is a very old one, especially when the Great Pyramid is considered. An alignment to the Pole star of the epoch, Thuban ( $\alpha$ Draconis) was first proposed by John Herschel in the mid-19th century but he later rectified his ideas when the geodesist Henry James proposed to him a much simpler mathematical and structural solution. ${ }^{46}$ Khufu's Great Pyramid - and several pyramids after his reign - adopted a standardized slope close to $26^{\circ} 33^{\prime}$ which corresponds to the simple ratio of 1 over 2 , which would have been very easily maintained in the course of the construction phases, and was very useful from the dynamic point of view for moving stones. However, the northern corridors of Sneferu's pyramids, which were indeed built earlier, showed a slightly higher slope,

The corresponding data is presented in Table 1 and illustrated in Figure 7. The northern descending corridors of both the Bent and the Red Pyramids were built with such a slope that, combined with the nearly perfect orientation, would allow the soul of the Pharaoh to reach Thuban, the pole star of 
the epoch (c. 2600 B.C.), when at lower culmination. ${ }^{47}$ Later pyramids might have adopted a simpler constructive technique - with a lower slope - although perhaps still roughly fulfilling this symbolic requirement, but probably this will always be a matter of debate.

Interestingly, the satellite pyramid corridor - also open to the north - has a slope of $34^{\circ}$. This would give a declination of $85^{\circ} 46^{\prime}$, which does not correspond to any singular star in the epoch. But, considering its proportions (base of 52 metres, height of 26 metres), the distance to the base of the Bent Pyramid $(55 \mathrm{~m})$ and the location of the gate of the corridor within the northern face of the small pyramid, the corridor would be pointing to the apex of $h^{-}-s n f r w-r s y$, precisely. This suggests the impressive image of the Bent pyramid acting like a huge pole or Axis Mundi with the northern stars - both circumpolar and nearly circumpolar - orbiting around it. Consequently, the northern orientation of the different elements of Sneferu's dual complex would work in the sense of facilitating the celestial ascent of the soul of the King among the imperishable stars.

We now consider the slopes of the faces of the pyramids, following an idea that was first developed by the first author a decade ago. ${ }^{48}$ The argument suggested is that not only the orientation but also the slopes of the pyramids would be the result of an intended astronomical design centred on the sun cult and the solar calendar. ${ }^{49}$ This would manifest itself in variants of solar hierophanies. One of the most conspicuous of such important effects would be produced when the ascending sun crosses the first vertical (the maximum circle crossing east, the zenith, west and the nadir in the celestial sphere), ${ }^{50}$ but on this particular occasion - at a very special epoch of the year, the summer solstice, when the sun had a declination of $\sim 24^{\circ}$ during the 4 th Dynasty. For a slope of $5412^{\circ}$, which is quite relevant for our interests (see Table 1), at the precise moment when the sun crosses the first vertical, the sunrays (which were already shining on the east and north faces of the pyramid) would almost simultaneously shine upon the south and west sides, so that the whole pyramid would be suddenly and completely illuminated for a few minutes, taking into account that the sun is not a point source but a disk with a diameter of 36'. Under this consideration, the phenomenon is not exclusive to this particular slope but would be common to most of the pyramids of the Old Kingdom built with inclinations between $52^{\circ}$ and $55^{\circ} .^{51}$

The effect would have been almost perfect for part of the structure of the first regular pyramid ever constructed, the Bent Pyramid (see Fig. 7). The lower section of this pyramid had an inclination of $54^{\circ} 28^{\prime}$. For the very accurate orientation of this monument, it gives a solar declination of $23^{\circ} 56^{\prime}$ for the observation of the phenomenon, consistent with the corresponding declination of the solar disc at the moment of the summer solstice for that epoch (between $\sim 2334^{\circ}$ and $\sim 2414^{\circ}$ ). ${ }^{52}$ The Bent Pyramid complex also included another suggestive hierophany related to the winter solstice, half a year later (see Fig. 2).

In contrast, the Red Pyramid had a much smaller slope (see Table 1), ${ }^{53}$ nearly identical to the uppermost section of the Bent Pyramid and to its much smaller satellite pyramid. However, as can be seen in Figure 2 and Table 1, the Red Pyramid had a pyramidion with a slope of 54³0', virtually identical to the lowermost section of the Bent Pyramid. Hence, for this smaller but singular structure, we would have had exactly the same effects as for the lower section of the Bent Pyramid. We can even speculate with a pyramidion, covered by gold or electron, crowning the Red Pyramid, having a singular illuminating effect and reflecting the solar light completely at the moment when the ascending sun crossed the first vertical during the summer solstice. From our point of view, this undoubtedly is another hint of the idea of a common dual project. ${ }^{54}$

It is now the moment to put into context why these slopes (and those for the Red and the uppermost section of the Bent Pyramids) were selected, as well as to ascertain the reason for such a curious dual architectural design. We are going to show evidence related to one extremely important cultural aspect of ancient Egyptian civilization, the creation and final adjustment of the civil calendar. ${ }^{55}$ The first author has defended the hypothesis that the civil year was inaugurated at the beginning of a lunar month following the summer solstice and hence in concordance with the moment of zenith pass of the sun at Elephantine. This was also the latest average date of the arrival of the flood at this particular spot and we can thus consider it as the beginning of a corresponding 'Nile year' ${ }^{56}$ It can easily be calculated that the earliest time in Egyptian history when 'Wepet Renpet' (I 3ht 1, or the 'First day of the first month of Akhet, the Inundation', i.e. Egyptian New Year's Eve), coincided with the summer solstice was in the four-year period centred more or less on 2760 B.C.

Considering that the new lunar month might have started as much as $291 / 2$ days later, this might have happened 118 years earlier. Also, considering reasonable uncertainties for the related astronomical phenomena, an error of roughly 72 civil years can be estimated. Summing up all these numbers, we reach an interval of roughly between 2950 B.C. and 2690 B.C. for the inauguration of the civil calendar (slightly later dates could also be acceptable). ${ }^{57}$ This is an interval of time more or less between the beginning and the end of the proto-dynastic period, when several relevant aspects of Egyptian civilization would have been developing, including the beginning of the solar cult which has been timed during the reigns of 
Hotepsekhemuy and Raneb (c. 2750 B.C.). ${ }^{58}$ Indeed, the calendar could be one of these innovations since it was plainly operative during the reign of Netjerkhet (c. 2670 B.C.). ${ }^{59}$ Another possibility is that it was implemented in the reign of Khasekhemuy, father and predecessor of Netjerkhet, just after the reunification of the country under his leadership c. 2690 B.C. This is a date at the lower limit of our interval and would have interesting chronological implications for the 4th Dynasty as will be discussed later on.

One question that could be asked is what would have happened once it became obvious that the civil calendar and the climatic (ecological) seasons were no longer in step, for example when I 3ht 1 was systematically ahead of the arrival of the inundation anywhere in Egypt. This may have happened some 120 to 200 years after the creation of the calendar, or nearly 500 years for a complete seasonal displacement (the complete flooding period occurring in the second season prt). Indeed, new systematic astronomical observations in connection with the solstices or other annual cyclic phenomena were needed in order to test the accurate behaviour of nature in relation to the civil calendar and the displacement of Wepet Renpet among the seasons. Our contention is that the relevance of solar observations during the earlier Pyramid Age and the introduction of the heliacal rising of Sirius (Peret Sopdet) as the harbinger of the Flooding, attested at least from the Middle Kingdom onwards, were the collateral effects of this necessity. Most probably, these observations started during the reign of Sneferu (see, for example, Fig. 2).

Why Sneferu? The civil calendar would have been probably established several decades before his reign and he, or his sages, could have felt the necessity to check the precise value of 365 days (perhaps they had already noticed a mismatch between the natural seasons - notably the Nile Floods and the civil calendar due to the shortfall of $\sim 1 / 4$ day in the civil year with respect to the tropical year). Hence, the huge burial monuments (or the much smaller pyramidion) of the King were constructed with such an astronomical design that through the illumination effects, the length of the solar year might be properly tested. It is certain that they must have detected that Wepet Renpet and the summer solstice were no longer coincident. Hence, the dual pyramid project included a new - strongly symbolic but also perhaps practical - innovation: a much lower slope for some elements of the King's burial complex started in his year 10/11: the uppermost layers of the southern Bent Pyramid, its satellite pyramid, and the slope of the core of the northern Red Pyramid (see Table 1).

Table 1 shows the value of the declination of the sun when it crosses the first vertical with an angular height of $c .4312^{\circ}$, corresponding to the slopes of the Red and the uppermost section of the Bent Pyramids. The declination is $c .20^{\circ} 6^{\prime}$, with an accuracy margin of $c . \pm 1 / 2^{\circ}$, considering the solar apparent diameter of 36' and reasonable errors in the precision of the measurements. This corresponds to May 20th in the Gregorian proleptic calendar and hence 32 days before the summer solstice, with a margin of a couple of days. ${ }^{60}$ Considering the wandering nature of the civil calendar, $128 \pm 8$ years must have elapsed since the inception of the civil calendar for such a deviation to be produced. This means that the dual pyramid complex of Sneferu at Dahshur should have been started, or at least designed, $128 \pm 8$ years after the official implementation of the civil calendar. This would mean that Sneferu's year 10/11 must fall in an interval between 2722 and 2562 B.C.

Most modern dates for the King's ascension to the throne have been postulated for the interval between 2649 and 2582 B.C. ${ }^{61}$ This certainly means that with the present uncertainty in the dating, a suggestive lightening phenomenon would have been produced at Wepet Renpet in the four sides of the Red and the upper section of the Bent pyramids which could have been used not only to calibrate the correct functioning of the civil calendar but also as a powerful source of symbolism. We propose the hypothesis that this was precisely the reason and main scope for the new slope used within the complex. ${ }^{62}$ Hence, this innovation was not caused by the necessity for correcting, or ameliorating, presumed structural problems as has been repeated ad nauseam but an intrinsic property of the dual pyramid complex design. This is an extremely important hint, and one never thought of before, for the idea of a unique gigantic project of Sneferu at Dahshur. We will see below that not only prosaic reasons but further strongly symbolic aspects were behind the idea.

The trial and error could have continued for at least another generation and perhaps later, until the civil year was finally fully operational in the reign of Menkaure, Sneferu's great-grandson. ${ }^{63}$ Later on, it would continue to be the 'most intelligent calendar ever invented' on Earth for another 4000 years. ${ }^{64}$ In the generations to come, the pyramids would keep these astronomical designs (orientation, illumination effects, etc.) for religious purposes (see below) and also for simple imitation, but neither the almost perfect orientations nor the striking features achieved by Sneferu (and Khufu) at the beginning of the 4th Dynasty were ever obtained again.

\subsection{Astronomy, architecture and symbolism.}


From the reign of Wenis, last king of the 5th Dynasty, onwards, the Pyramid Texts were inscribed in the interior chambers of sovereigns' pyramids. These texts had a marked sense of astronomical symbolism that can be traced in the various aspects of the king's ascension to the sky and his various sorts and manners of astral manifestations within the celestial vault. ${ }^{65}$ Especially relevant for our purposes are the mention both in the Pyramid Texts and in the later Coffin Texts of the presence of the king's crowns as virtual realities in the sky. ${ }^{66}$

Katja Goebs has deeply analysed this possibility. ${ }^{67}$ On the one hand, she has proposed that the texts mentioning the White Crown of Upper Egypt, $h \underline{d} t$, could be better understood if this is seen as a kind of bright white, or silver, light in the sky, notably the planet Venus and/or the Moon. ${ }^{68}$ On the other hand, those text mentioning the Red Crown of Lower Egypt, $d \check{r} r$, would suggest that this could be identified with the red aspect of the sky, notably at dawn (or dusk), or even with the reddish rising sun-disc. ${ }^{69}$ These arguments are nicely illustrated in Figure 8. There are, however, other interesting possibilities that Goebs has not taken into account, and that would perfectly - and in some cases even better - fit what is written within the corresponding spells of the Pyramid Texts, which might be complementary to the previously discussed symbolism. We are referring to the pale white luminous aspect of the zodiacal light, for the case of the White Crown, and of the aurora borealis for the case of the Red one (see Fig. 8).

The relevance of zodiacal light has already been considered in the context of pyramid symbolism, ${ }^{70}$ and this beautiful celestial phenomenon would even conspicuously fit the standard shape of the White Crown, especially when enhanced by the presence in the Ecliptic of some of the planets, notably Venus, as shown in Figure 8 (see also Fig. 5). The aurora borealis is visible at Egyptian latitudes (see Fig. $8),{ }^{71}$ and may certainly have impressed the ancient Egyptians with its spectacular reddish glare filling the northernmost half of the celestial vault and behaving in quite a similar fashion as the light of dawn but concentrated in the northern section of the sky (remember that the Red Crown was that of Lower Egypt, hence the north). There is other evidence that might further support the symbolic equivalence of the celestial Red Crown with the aurorae at least on certain occasions. The northern lights could also adopt a green hue. This would explain why in the Pyramid Texts seldom mention the flattened crown of the north (the determinative is clear) as $w 3 \underline{d} t$, the Green Crown, ${ }^{72}$ something that has puzzled scholars dealing with these texts, and that might easily be explained within this context. ${ }^{73}$ Of course, Egyptian religious texts are open to many readings, and several plausible interpretations could be correct at the same time. ${ }^{74}$

The question now is whether the two pyramids of Sneferu at Dahshur, that we have seen (see section 2.4) can possibly and reasonably be identified as huge symbolic representations of $h \underline{d} t$, for the Bent Pyramid materialization in white and red stone, respectively, of celestial realities that were most relevant for the astralization, and hence the eternal life, of the king after death, as beautifully expressed in the Pyramid Texts two hundred years later. Indeed, our hypothesis is that this was the case and that the pyramids were gigantic, physically real, but symbolic manifestations of the eternal power of the king (see Fig. 5). This once more would speak of a unified project that would allow the king to manifest himself, both during his lifetime and after death, as conspicuous celestial aspects of kingship and the divine.

\section{CONCLUSIONS}

It is our contention that the hypothesis that the two great pyramids of Sneferu at Dahshur were conceived as a unitary project is indeed the only one capable of fitting together the information contained in the Royal Annals with all the other clues, of a different nature and origin, that we have discussed in this paper. In the reality charged with symbolism on a truly gigantic scale. The story may have been as follows: in year 8 or 9 of his reign, and for unknown reasons, King Sneferu decided to abandon his necropolis at Meidum, founding a new residential area at the limits between Upper and Lower Egypt (see Fig. 1). Next to it, a new, unique project of a dual nature was developed for the Pharaoh's afterlife but also as a true image of his overwhelming power in life. This was conceived as a funerary complex integrated by two gigantic pyramids (with their respective mortuary temples), a satellite pyramid (perhaps for the Ka of the King) and (at least one) 'Valley' temple (see Fig. 2).

The two (Bent and Red) pyramids would be the demonstration of the sovereign's power as dualking of Upper and Lower Egypt by symbolic imitation (colour, location, and perhaps also in the form of the monuments themselves, bent and flat, respectively) of the White and Red Crowns of Upper and Lower Egypt (see Figs. 4 and 5). ${ }^{75}$ The interchangeable slopes of the pyramids were well defined with a peculiar astronomical symbolism (summer solstice and New Year's Eve) that could be related to the invention and further development of the Egyptian civil calendar. Astronomical alignments would also be included accordingly (see Figs. 6 and 7). The pyramids were almost perfectly orientated towards the north, ${ }^{76}$ to the 
realm of the imperishable stars, and the access corridors were built with a slope that would facilitate the ascent of the king to the northern skies. Besides, the pyramids themselves could be associated with celestial phenomena concomitant with the manifestation of the king's power in his afterlife, notably either the zodiacal light or Venus (or both) for the White Crown, $h \underline{d} t$, and the aurora or the light of dawn for the Red Crown, $d \check{r} r t$ (see Fig. 5). The pyramids might then be considered as petrified light. This astronomical symbolism would be put into writing two hundred years later in the 5th and 6th Dynasty Pyramid Texts.

Sneferu presumably died in the 31 st year of his reign leaving unfinished the structures associated with the Red pyramid, ${ }^{77}$ notably his mortuary temple, which was quickly finished in mud-brick by his elder surviving son and successor Khnum Khufu (Cheops). Since his father had constructed a huge dual project, Khufu (c. 2550 B.C.) might have decided that he could not be less than his predecessor and decided to plan another dual project but on an even larger scale. This unitary project would be integrated by two huge pyramids (larger than any of his father's), a huge statue of himself as a twin of the sun god (the Sphinx), associated temples and causeways and a huge cemetery for the members of the royal family (the first occasion of a square grid in monumental construction). The new pyramid complex would receive the name $3 h t h w f w$, 'the Horizon of Cheops' (see Figure 9). The idea of a unique project for the two largest pyramids of Giza was independently developed by the two authors in the mid-2000s. ${ }^{78}$ Actually, the possibility that both father and son envisaged their burial monuments on such a gigantic scale may suggest a common interest in a unified project in both cases and, from a historical, social and dynastic perspective, could offer further support for the idea of two subsequent unitary dual projects. ${ }^{79}$

The main difference would have been that Sneferu had the time to complete, or nearly complete, his project while his son Khufu possibly left his unfinished after a long but shorter reign of at least 27 years. ${ }^{80}$ This would have permitted that his younger son, and second successor, Khaefre, had been the one in charge of accomplishing the gigantic plan by simply 'usurping' nearly half of his father's project and assuming it as his own burial complex under the name of $w r h^{\complement} f r^{\top}$, 'Khefren is great'. ${ }^{81}$

Architecture is perhaps the most obvious way to indicate the enduring power of a ruler, both during his lifetime and long after his death. ${ }^{82}$ The pyramids, which still dominate the skyline of the Nile for dozens of kilometres, even after thousands of years of erosion and human barbarism, would when newly constructed have glistened under the glare of the bright Egyptian sun and had been a constant reminder for kilometres around that the double-king had the power and resources not only to control the lives of his subjects but also to change the shape of the landscape itself. Sneferu indeed was a specialist in such a task.

\section{ACKNOWLEDGEMENTS}

This is possibly one of the last papers that will be received by Prof. Michael Hoskin as editor of the Journal for the History of Astronomy. The authors would like to express their gratitude to Prof. Hoskin for his extraordinary labour as editor of the journal, making of JHA a reference publication in the field for nearly half a century. His support for cultural astronomy research (via Archaeoastronomy Supplement and later) has indeed been a boost for the recognition of archaeoastronomical studies within the academic community. We also wish to express our sincere acknowledgement to our colleagues César González and Manuel Vázquez, for valuable discussions on the potentially revolutionary ideas expressed in this paper. Corrections, comments, suggestions and constructive critics from the Egyptologists Rolf Krauss, José Lull and José Miguel Parra and a couple of anonymous referees greatly enriched the quality of the paper. This work is partially financed in the framework of the projects P310793 'Arqueoastronomía' of the Instituto de Astrofísica de Canarias, and AYA2011-26759 'Orientatio ad Sidera III’ of the Spanish MINECO.

\section{REFERENCES}

1. This idea was first put in print by the first researcher to conduct serious investigation at Dahshur necropolis using modern methodology, the Egyptian Egyptologist Ahmed Fakhry. See A. Fakhry, The monuments of Sneferu at Dahshur (Cairo: General Organization for Government Print Offices, 1959). The idea has since then been repeated in academic sources and popular literature without much further questioning. See for example: I.E.S. Edwards, The Pyramids of Egypt, 3rd ed. (Harmondsworth: Penguin, 1993); M. Lehner, The complete pyramids (London: Thames and Hudson, 1997); and M. Verner, The pyramids: the mystery, culture, and science of Egypt's great monuments (New York: Grove Press, 2002). For a contrary opinion, namely that the change of slope was not caused by structural problems in the Bent Pyramid, see A. Varille, A propos des pyramides de Snefrou (Cairo: IFAO, 1947), 7-8, who wrote: 'Tout d'abord la pyramide à été prévue, des le débout des travaux, pour avoir deux pentes. Tout y est l'expression d'une dualité'. 
More recently see, J.M. Parra, "Houni et Snéfrou: les pyramides de Meïdoum et Dahchour", Göttinger Miszellen cliv (1996) 77-91, and J.M. Parra, Historia de las pirámides de Egipto (Madrid: Editorial Complutense, 1997), 114-5, for a similar opinion.

2. G. Magli, Architecture, Astronomy and Sacred Landscape in Ancient Egypt (Cambridge: Cambridge University Press, 2013), 57-71.

3. As poetically expressed by R. Kapuściński, Imperium (Warsaw: Czytelnik, 1993).

4. Egyptian chronology for the Old Kingdom is highly disputed. See, for example, J.A. Belmonte and M. Shaltout (eds.), In search of cosmic order, selected essays on Egyptian archaeoastronomy (Cairo: Supreme Council of Antiquities Press, 2009), Appendix I, 339-46. The date selected, 2575 B.C. is close to the ascension of Sneferu according to E. Hornung, R. Krauss and D. A. Warburton (eds.), Ancient Egyptian chronology (Handbuch der Orientalistik, lxxxiii; Berlin: Brill, 2006), who proposed the intervals 2568-2535 to 2543-2510 B.C. (the earliest ascension date at 2578 B.C.) for his reign - a low chronology -. Other dates published in literature are a high chronology (2613-2589 B.C.), according to I. Shaw (editor), The Oxford History of ancient Egypt (Oxford: Oxford University Press, 2000), or a very low one (2520-2470 B.C.), according to A. Dodson and D. Hilton, The complete royal families of ancient Egypt (London: AUC Press, 2004). Another often referred to chronology for Sneferu is 2639/2604 to 2589/2554 B.C. according to J. von Beckerath, Chronologie des pharaonischen Ägypten (Mainz: Philipp von Zabern, 1997). More recently, C. Bronk Ramsey, M. W. Dee, J. M. Rowland, T. F. G. Higham, S. A. Harris, F. Brock, A. Quiles, E. M. Wild, E. S. Marcus, and A. J. Shortland, "Radiocarbon-based chronology for dynastic Egypt", Science 328 (2010), 1554-57, have presented a Bayesian approach to the problem of radiocarbon dates showing that Ian Shaw's chronology is perhaps the most realistic. However, they have used certain circular arguments and a poor statistics for the data of the Old Kingdom: see J.A. Belmonte, Pirámides, templos $y$ estrellas: arqueología y astronomía en el Egipto antiguo (Barcelona: Crítica, 2012), 332-5.

5. For a discussion on the length of Sneferu's reign see: R. Krauss, “The length of Sneferu's reign and how long it took to build the "red pyramid"”, Journal of Egyptian Archaeology lxxxii (1996), 43-50. The highest preserved date is the year of the 24th occasion [of the cattle count], tht or 'tenet' for the ancient Egyptians. Prior to Sneferu's reign cattle counts were handled once every two years, with a year after [the cattle count] between them. Reign lengths have often been calculated doubling the highest $t n t$, accordingly. However, J. S. Nolan, "The original lunar calendar and cattle counts in Old Kingdom Egypt", Aegyptiaca Helvetica xvii (2003), 75-97, has proven that this was not the case from the reign of Sneferu onwards, suggesting that there was one "year after" for an average of 2.83 years of [nearly a proportion 3:1]. The 24th tht would then correspond to year 31 with a pessimistic margin of a couple of years.

6. A. Ćwiek, "Date and Function of the so-called Minor Step Pyramids", Göttinger Miszellen clxii (1998), 39-52. See also, A. Dobson, "The Multiple Pyramids of Snefru", in The Seventy Great Mysteries of Ancient Egypt, edited by B. Manley (London: Thames and Hudson, 2003), 57-60. More recently, see R. Stadelmann, "Snofru: builder and unique creator of the pyramids of Seila and Meidum". In Echoes of eternity: studies presented to Gaballa Aly Gaballa, edited by O. ElAguizy and M. Sherif Ali (Wiesbaden: Harrassowitz, 2010), 31-8. For the recently excavated pyramid at Edfu (El Ghoneimiya), see: G. Marouard and H. Papazian, "The Edfu Pyramid Project: recent investigation at the last provincial step pyramid", The Oriental Institute News and Notes ccxiii (2012), 3-9. Additionally, F.L. Borrego Gallardo, "Lord of Maat: innovation and change of the Egyptian divine kingship under the reign of Snefru", ARYS: Antigüedad, Religiones y Sociedades xii (2014), in the press, includes the most recent discussion on the topic.

7. J. A. Belmonte, M. Shaltout and M. Fekri, "Astronomy and landscape in ancient Egypt: challenging the enigma of the minor step pyramids", Papers on ancient Egypt (TdE) 4 (2005), 718.

8. D.A. Cintron, 2003, "A new angle on Sneferu's pyramids", who has argued that 'the pyramid complex of Dahshur was designed as a unified whole from the beginning as a dual pyramid necropolis and that this design was carried out exactly to Sneferu's satisfaction'. This paper is the unpublished outcome of a presentation at the 54th Annual Meeting of the American Research Centre of Egypt, in Cairo in 2003. http://www.cintronics.com/pdffiles/SneferuPyramids.pdf.

9. For an earlier discussion on this topic, see A. Fakhry, The pyramids (Chicago/London: University of Chicago Press, 1961), 73. For a detailed argument, see: R. Stadelmann, "Snofru und die Pyramiden von Meidum und Dahshur", Mitteilungen des Deutschen Archäologischen Instituts xxxvi (1980), 437-49. 
10. For a recent analysis of the Palermo Stone, see T.A.H. Wilkinson, Royal Annals of ancient Egypt: the Palermo Stone and its associated Fragments (New York / London: Kegan Paul, 2000). For the Pyramid Texts, a classical work is R.O. Faulkner, The ancient Egyptian Pyramid Texts (Oxford: Oxford University Press, 1969). For a more recent work on the topic, see: J. P. Allen and P. Der Manuelian, The ancient Egyptian Pyramid Texts. Writings from the Ancient World (Ann Arbor: Society of Biblical Literature, 2005).

11. ... 'the turning point in pyramid masonry came at the beginning of the Fourth Dynasty when at the Bent Pyramid the courses of the core were set horizontally for the first time and the casing blocks were set nearly so, ...' D. Arnold, Building in Egypt: Pharaonic stone masonry (Oxford/New York: Oxford University Press, 1991), 159.

12. Fakhry, op. cit. (ref. 1). Also relevant is Fakhry, op. cit. (ref. 9), 97, who was convinced that the Bent Pyramid - the upper chamber at the end of the western corridor - was the actual burial place of Sneferu.

13. See the discussion on the tenet $[$ tht $]$ in ref. 5.

14. See R. Stadelmann, Die ägyptischen Pyramiden. vom Ziegelbau zum Weltwunder (Mainz: Philipp von Zabern, 1985), and, more recently, R. Stadelmann, "Inscriptional evidence for the reign of Sneferu at Dahshur". In Chronology and archaeology in ancient Egypt (the third millennium B.C.), edited by H. Vymazalová and M. Bárta (Prague: Czech Institute of Egyptology, 2008), 104-10. See also Krauss, op. cit. (ref. 5).

15. Once finished, this chamber was not aired and the more than probable problem generated by rarefied air and extreme heat was perhaps on the origin of the airshafts at Sneferu's son Great Pyramid at Giza. See G. Magli and J.A. Belmonte, "Pyramids and star, facts, conjectures and starry tales", in In search of cosmic order, selected essays on Egyptian archaeoastronomy, edited by J.A. Belmonte and M. Shaltout (Cairo: Supreme Council of Antiquities Press, 2009), 305-22. For a more recent analysis, see M. Haase, 2011. "Dienten die oberen Schächte in der Cheops-Pyramide zur Belüftung der Grabkammer?" In Times, signs and pyramids: studies in honour of Miroslav Verner on the occasion of his seventieth birthday, edited by V.G. Callender, L. Bareš, M. Bárta, J. Janák, and J. Krejčí (Prague: Faculty of Arts, Charles University in Prague. , 2011), 135-56.

16. Ahmed Fakhry, op. cit. (ref. 1) elaborated this idea, once the Bent pyramid was clearly assigned to Sneferu. However, when reviewing this paper, César González-García has pointed out the fact that to solve a problem of instability by adding more weight to the structure was not a very clever idea. Even with the lesser slope, the amount of stone in the upper section of the Bent pyramid would be $\sim 67 \%$ of the one that would have been present providing the older slope was kept saving only $10 \%$ of the total volume of stone of the pyramid -, still being a huge additional weight for a building that was supposed to be under the risk of collapse.

17. V. Maragioglio and C. Rinaldi, L'architettura delle piramidi Menfite, Vol. III (Turin: Artale, 1963).

18. However, Fakhry attributed the dismantling of the structure to the excavations of A.M. Hussein (1946-49). These works were never published. The idea of a later earthquake would agree with Fakhry's (see ref. 12) suggestion that the Bent pyramid was his actual tomb.

19. Curiously, according to S. Yoshimura, T. Nakawaga, and S. Tonouchi, "Non-Destructive Pyramid Investigation (2)", Studies in Egyptian culture viii (Tokyo: Waseda University, 1988), data on micro-gravimetric prospects, there would be an additional chamber and corridor inside the Great Pyramid that are yet to be archaeologically confirmed. This has led Parra (2008), op. cit. (ref. 1, 2nd edition), 203-8, to suggest that perhaps Khufu imitated his father Sneferu's western apartment in his own pyramid.

20. G. Magli, "Geometry and perspective in the landscape of the Saqqara pyramids", APLIMAT Journal of Applied Mathematics iii (2009), 147-59.

21. G. Dreyer, Umm el-Qaab 1: Das prädynastische Königsgrab U-j und seine frühen Schriftzeugnisse (DAI Archäologische Veröffentlichungen lxxxvi, 1998).

22. G. Magli, "From Abydos to the Valley of the Kings and Amarna: the conception of royal funerary landscapes in the New Kingdom", Mediterranean Archaeology and Archaeometry xi (2011), 23-36. It could be argued that the pyramids have sharp apexes instead of the slender slope of the $\underline{d} w$ sign, but during the New Kingdom, the equivalence was pretty obvious in the name of the Sphinx, Hor-em-akhet (see Fig. 9).

23. Senuseret III would have looked for an analogy with the 'Mountain of Anubis' to the south of Umm el-Qab. See J. Wegner, "The tomb of Senwosret III at Abydos: considerations on the origins and development of the Royal Amduat Tomb", in Archaism and innovation: studies in the 
culture of Middle Kingdom Egypt, edited by D. Silverman, W.K. Simpson and J. Wegner (New Haven: Yale University Press, 2009), 103-169.

24. Magli, op. cit. (ref. 20). An updated and extended discussion on the topic can be followed in Magli, op. cit. (ref. 2). It is however worth mentioning that, according to José Lull and José Miguel Parra, the final accomplishment of a $\underline{d} w$ symbolism could be a later decision of Shepseskaf once the visualization of the idea was 'obvious'.

25. G. Magli, "The Snefru projects and the topography of funerary landscapes during the 12th Egyptian Dynasty", Time and Mind v (2011), 53-72.

26. Lehner, op. cit. (ref. 1), 34-5.

27. J. Assmann, "Creation Through Hieroglyphs: The Cosmic Grammatology Of Ancient Egypt", in The poetics of grammar and the metaphysics of sound and sign, edited by S. La Porta and D. Shulman, Jerusalem Studies in Religion and Culture vi (Leiden: Brill, 2007), 17-34.

28. S. Quirke, The cult of Ra (London: Thames and Hudson, 2001), 116.

29. The question of the names of the pyramids has been a matter of some debate. Some scholars would have read the name of this pyramid as 'The Pyramid of Sneferu is Durable'. However, most recently, the second alternative, with the name of the pyramids as an appellative of the defunct king has received more support, but the question is far from being resolved. For a very interesting discussion on the different possibilities of reading the names of the pyramids, see $\mathrm{H}$. G. Fisher, "On the interpretation of names of the pyramids", Egyptian studies, iii: Varia nova (New York, 1996), 73-7.

30. D.B. Redford, History and chronology of the Eighteenth Dynasty of Egypt: seven studies (Toronto: University of Toronto Press, 1967), 4-27.

31. An excellent discussion on this topic can be followed in Katja Goebs' $\mathrm{PhD}$ dissertation. This has been published as K. Goebs, Crowns in Egyptian funerary literature: royalty, rebirth, and destruction (Oxford: Griffith Institute Monographs, 2008). Particularly relevant is the information collected in section 1.3, 24-31.

32. A. Moret, "Chartes d'immunité dans l'Ancien Empire égyptien,", Journal Asiatique xi (1917), 10, 359-447. This must be understood as a clue for a common project only. See also Magli, op. cit. (ref. 2), 68-9.

33. L Borchardt, "Denkmäler des Alten Reiches (ausser den Statuen) im Museum von Kairo". Catalogue Général des Antiquités Égyptiennes du Musée du Cairo I (Berlin: Reichsdruckerei, 1937).

34. As already mentioned, the most recent analysis of the annals is: Wilkinson, op. cit. (ref. 10). There are three clear entries for the reign of Sneferu.

35. Goebs, op. cit. (ref. 31), 25.

36. Wilkinson, op. cit. (ref. 10), 142. However, according to the hieroglyphic copy in Urk. I, 236, 11 , the sign would be $\check{s} m^{c}$, and not $r s y$. This might include a certain hue in the reading.

37. Wilkinson, op. cit. (ref. 10), 144-5.

38. There is no archaeological evidence of such a building. However, exactly the same solution would have been adopted at the beginning of the Middle Kingdom when Amenemhat I founded a new administrative capital Ittawy, 'Who grabs the Two lands', a few kilometres to the south of Dahshur, erecting a new necropolis nearby (present El-Lisht) where his pyramid and the one of his son Senuseret I would be constructed. Both monuments had names selected accordingly. See Lehner, op. cit. (ref. 1), 168-73. It is however fair to note, as Rolf Krauss pointed out, that the determinative of pyramid $\triangle$ is not written in the relevant entry of the Palermo stone (see Fig. 4), although the text is rather wordy in that particular section.

39. See Stadelmann, 2008, op. cit. (ref. 14). Even if we suppose a nearly contemporary building, then some nine years (between years of the 8th and 15th occasions) look reasonable time to prepare the terrain, excavate the huge pits of the lower chambers of the Red Pyramid, put in place the huge corbelled vaults of the ceilings of the lower rooms and prepare the foundation platforms and trenches to start settling the different layers. Interestingly, see W.S. Smith, "Inscriptional evidence for the history of the Fourth Dynasty", Journal of Near Eastern Studies xi (1952), 11328 , for an earlier opinion that it seems impossible that the quarry marks could have been applied at the beginning of the construction of the Red Pyramid but rather when it was nearly completed.

40. Krauss (private communication) has argued that if any pyramid symbolized anything it was presumably not on the basis of its building materials. It could reasonably be argued that the Red pyramid was cased with white limestone and the 'final' aspect of the pyramid would have been that of a white shining gem. However, while the casing of the Bent Pyramid is almost intact, that of the Red Pyramid has nearly completely disappeared (see Fig. 2). Perhaps the pyramid was left 
unfinished due to the death of the King in his year 31, or it is indeed possible that there was no intention of completely casing it in white limestone. Only some sections of the lowest courses have survived in situ, which is surprising considering that the general idea is that the casing blocks of Tura limestone of the Red Pyramid were used to burn lime in Roman times. Curiously, the white limestone pyramidion (a tiny fraction of the total casing) was found in fragments during the excavations of the funerary temple and, under this consideration, it would be reasonable to assume that more rubble of the rest of the hypothetical white limestone casing should have been found on the site if this was ever finished. Interestingly, when just excavated, the pyramidion showed traces of a red pigment that could be either painting or rock oxidation, see Stadelmann, 1985, op. cit. (ref. 14). If they were rests of painting, it may after all suggest that the Red Pyramid could have been painted red once finished.

41. This idea was firstly defended by Cintron, op. cit. (ref. 8).

42. A comprehensive summary of the idea can be found in J.A. Belmonte, M. Shaltout and M. Fekri, "Astronomy, landscape and symbolism: a study on the orientations of ancient Egyptian temples", in In search of cosmic order, selected essays on Egyptian archaeoastronomy, edited by J.A. Belmonte and M. Shaltout (Cairo: Supreme Council of Antiquities Press, 2009), 211-82. The origin of Egyptian archaeoastronomy can be traced to the year 1894 with the publication of J. N. Lockyer, The Dawn of Astronomy, new edition (New York: Garland Publishing, 1993). However, a discussion on the first serious attempts to analyse Egyptian sacred building orientations can be followed in E.C. Krupp, "Light in the temples", in Records in stone, papers in memory of Alexander Thom, edited by C. L. N. Ruggles (Cambridge: Cambridge University Press, 1988), 473-99. An important preliminary study on the orientation of temples is also provided by C. Leitz, Studien zur ägyptischen Astronomie (Wiesbaden: Ägyptologischen Abhandlungen Band xlix, 1991).

43. For the so-called stellar simultaneous transit theory, see K. Spence, "Ancient Egyptian chronology and the astronomical orientation of pyramids", Nature no. 408 (2000), 320-4; and J. A. Belmonte, "On the orientation of the Old Kingdom pyramids", Archaeoastronomy no. 26 (2001), S1-20. A recent updating of the theory has been outlined by Belmonte, op. cit. (ref. 4), 169-214. This would still work independently of the validity, or not, of the error versus time trend (related to precession) originally defended by Spence. For the 'stretching of the cord ceremony', see J.A. Belmonte, M.A. Molinero and N. Miranda, "Unveiling Seshat: new insights into the stretching of the cord ceremony", in In search of cosmic order, selected essays on Egyptian archaeoastronomy, edited by J.A. Belmonte and M. Shaltout (Cairo: Supreme Council of Antiquities Press, 2009), 193-210. See also Fig. 6.

44. For Meskhetyu, see J. Lull and J. A. Belmonte, "A firmament above Thebes: uncovering the constellations of ancient Egyptians", Journal for the History of Astronomy xxxvii (2006), 373-92 (and references therein); or the most recent updated and enlarged J. Lull and J. A. Belmonte, "The constellations of ancient Egypt", in In search of cosmic order, selected essays on Egyptian archaeoastronomy, edited by J.A. Belmonte and M. Shaltout (Cairo. Supreme Council of Antiquities Press, 2009), 153-92.

45. Allen and Der Manuelian, op. cit. (ref. 10), 11-2.

46. Herschel wrote the following in a letter to James: 'The inclination of the passages I used to think quite satisfactorily accounted for by being able to see Alpha Draconis through them; now you have shown a practical and assuredly very natural reason in pointing out $26^{\circ}$ as the "angle of rest", facilitating the sliding down of great weights without incurring a "down-rush", and directly subserving the intention of blocking up the access to the burial chamber'. See R. Krauss, "La orientación de los corredores de las pirámides egipcias según John Herschel", in Trabajos de arqueoastronomóa: ejemplos de África, América, Europa y Oceanía, edited by J. Lull (Gandía: Agrupación astronómica de La Safor, 2006), 185-92.

47. There is a discrepancy between our own datum on the slope of the Red Pyramid northern corridor (checked on site with a precision of $1 / 4^{\circ}$ ) and other measurements reported in literature which give a value of $c .26^{\circ} 34$ ', see R. Krauss, "Weisen die Pyramidenkorridore den Weg zum Himmel?", Studien zur altägyptischen Kultur xxxviii (2009), 151-9, Table 1. If this were the correct number for the slope, it would possibly mean that the ratio 2:1 was already an innovation of Sneferu's reign. In this sense, it is worth noticing that the alignment to Thuban was more precise for the pyramid of Meidum, where the corridor has a slope of $\sim 28^{\circ}$ with an average deviation from the north of $-18^{\prime}$, giving a declination of $88^{\circ} 30^{\prime}$, accurately corresponding to the declination of $\alpha$ Draconis $c .2600$ B.C. This star presumably belonged to one of the 'Mooring Post' constellations of the ancient Egyptians. See Belmonte, op. cit. (ref. 4), Table 3.1. The 
ascending corridor of the western apartment of the Bent Pyramid will be discussed later on, see (ref. 60).

48. In a contribution to the SEAC XIII conference hold in Isili (Sardinia) in June 2005. See J.A. Belmonte and M. P. Zedda, "Light and shadows on the pyramids", in Light and shadows in cultural astronomy, ed. by M. Zedda and J. A. Belmonte (Cagliari: Agorà Nuragica, 2007), 188196.

49. The inspiration came from the work of D. Magdolen, "The solar origin of the sacred triangle in ancient Egypt", Studien zur Altägyptischen Kultur xxviii (2000), 207-17.

50. For the definition of astronomical terms that could be useful for Egyptology, see M. Shaltout and J.A. Belmonte, "Introduction: under ancient Egyptian skies", in In search of cosmic order, selected essays on Egyptian archaeoastronomy, edited by J.A. Belmonte and M. Shaltout (Cairo: Supreme Council of Antiquities Press, 2009), 11-26.

51. See Belmonte, op. cit. (ref, 4), Table 5.1. Several later pyramids were built with designs including very simple mathematical relationships such as a ratio 14/11, with a slope of $c$. $51^{\circ} 50^{1 / 2}$ ' - Sneferu's final project at Meidum, Khufu's Great Pyramid or Niuserre's one at Abusir-, or the very comfortable Pythagorean triangle 3-4-5, slope of $53^{\circ} 7{ }^{\prime} 48^{\prime \prime}$ - Khaefre's pyramid and the majority of 6th Dynasty pyramids.

52. For whatever reason, the pyramids of Amenemhat I in El-Lisht and that of Amenemhat III in Dahshur were built with slopes very close to the lower section of the Bent pyramid, thus having an identical solar phenomenology. See also Magli, op. cit. (ref. 25). At the beginning of the Middle Kingdom, Wepet Renpet was happening in dates close to another very important station of the solar cycle: the winter solstice.

53. It has been suggested that this slope obeyed a design that followed a Pythagorean triangle of 2021-29. See C. Rossi, Architecture and Mathematics in Ancient Egypt (Cambridge: Cambridge University Press, 2004). However, this mathematical approach does not explain why this new slope was selected. Actually, the two explanations are not mutually exclusive, since there is no doubt that in practice Egyptian architects used rational fractions to express angles.

54. However, Rossi, op. cit. (ref. 53), has argued - indeed without further evidence - that the pyramidion found at the Red Pyramid temple would actually have been the one originally built for the Bent Pyramid prior to the change of slope, that was later abandoned and, for unknown reasons, deposited in the final resting place of Sneferu at the Red Pyramid complex.

55. This was first proposed by Belmonte and Zedda, op. cit. (ref. 48).

56. For a discussion on the solar origin of the civil calendar, see J.A. Belmonte, "Some open questions on the Egyptian calendar: an astronomer's view", Trabajos de Egiptología (Papers on Ancient Egypt) no. 2 (2003), 7-56. For an updated version of this work, see J.A. Belmonte "The Egyptian calendar: keeping Ma'at on Earth", in In search of cosmic order, selected essays on Egyptian archaeoastronomy, edited by J.A. Belmonte and M. Shaltout (Cairo: Supreme Council of Antiquities Press, 2009), 73-130. Alternatively, L. Depuydt, Civil and lunar calendar in ancient Egypt (Leuven: Orientalia Lovaniensia Analecta lxxvii, 1997) defends the very importance of the moon in Egyptian calendrics, while A-S. von Bomhard, The Egyptian calendar, a work for eternity (London: Periplus Publishing London Ltd., 1999), defends a stellar origin based on Sirius observations. A. Spalinger, "Egyptian festival dating and the moon", in Under one Sky, ed. by J. M. Steele and A. Imhausen (Münster: Ugarit Verlag, 2002), 379-404, offers an open discussion on the topic.

57. For a complete discussion on the errors, see Belmonte (2003), op. cit. (ref. 56).

58. According to J. Kahl, Ra is my lord: searching for the rise of the sun god at the dawn of Egyptian history (Weisbaden: Harrassowitz, 2007). Also relevant is R. Krauss, "Stellar and solar components in ancient Egyptian mythology and royal ideology", in Astronomy and power, edited by M. Rappenglück and B. Rappenglück, British Archaeological Report Int. Ser. (2015), in press.

59. Bronk Ramsey et al. op cit. (ref. 4) has fixed a date between 2691 and 2651 B.C. for the ascent of Netjerkhet, according to a set of radiocarbon dates of his reign.

60. The civil calendar moves one day ahead every four years with respect to the Gregorian proleptic calendar. The two days error - corresponding to 8 years - is due to the fact that the latter is only an average of the actual tropical year of 365.2425 days in Antiquity. In this respect, we have so far not dealt with the two distinct slopes of the corridor reaching the western apartment of the Bent Pyramid of Sneferu. This started with a slope of $24^{\circ} 17^{\prime}$ but reached the surface of the pyramid western face at an inclination of $30^{\circ} 9^{\prime}$ (see Table 1 and Fig. 7). These correspond to 'declinations' of $11^{\circ}$ and $14 \frac{1}{2^{\circ}}$, respectively. The only relevant one would in principle be the 
latter since this was the one reaching the surface. There is hardly any relevant star at that declination for the epoch of Sneferu. If, on the contrary, we consider an alternative solar alignment, this declination would fit to the sun at April 30th or August 13th in the Gregorian proleptic calendar. We could speculate that either of these two dates was relevant for Sneferu's reign (perhaps his date of ascension to the throne or something similar). However, if May 20th is to be considered as a possibility for Wepet Renpet sometime during the reign of Sneferu, these two dates would correspond to IV Shemu 15 and III Akhet 25 in the civil calendar of the time, respectively. The former does not seem relevant apart from being the mid-month of Mesore, the month celebrating the birth of the sun. The latter corresponds to the minor Middle Kingdom festival of šst itrw whose relevance we simply do not know although it was certainly linked to the important festival of Peret Sopdet. Before anyone else arguing in this respect, it is worth noting that August 13th and April 30th were especially relevant dates in Mesoamerican calendrics. We indeed believe this is pure chance!

61. Bronk Ramsey et al., op. cit. (ref 4). Two dates have been previously discussed for the inauguration of the civil calendar: c. 2750 B.C. for the first Pharaohs of the 2nd Dynasty, and $c$. 2690 B.C. for the reign of Khasekhemuy. This would give either 2622 B.C. or 2562 B.C., with a margin of \pm 8 years, for Sneferu's 8th $t h t$. This offers two possibilities for Sneferu's 31 year reign: $c$. $2632-2601 \pm 8$ B.C. or $c$. $2573-2542 \pm 8$ B.C., in relatively good agreement with the standard high and low chronologies considered so far (see ref. 4). The authors would tend to support the lower one since Belmonte, op. cit. (ref. 4), 335-8, has proposed, on an archaeoastronomical basis, $c .2550 \pm 10$ B.C. as the date for the ascension of Khufu, the Great Pyramid builder and son and successor of Sneferu.

62. The small pyramid has a slope of $c$. $44^{\circ} 30^{\prime}$. This would give a declination of $20^{\circ} 21^{\prime}$, which corresponds to May 22nd in the Gregorian proleptic calendar. This may suggest that the satellite pyramid could have been planned, or at least started, 8 years prior to the other components of the complex with a similar slope (i.e. the upper layers of the Bent Pyramid and the Red Pyramid). This is indeed plausible. However, considering the margin of error of \pm 8 years, this hypothesis must be viewed with caution.

63. Belmonte, op. cit. (ref, 4), Table 5.1.

64. O. Neugebauer, The exact sciences in Antiquity (New York: Dover, 1969).

65. R. Krauss, Astronomische Konzepte und Jenseitsvorstellungen in den Pyramidentexten, (Wiesbaben: Ägyptologische Abhandlung Band lix, 1997).

66. For the Coffin Text's astronomical aspects see: P. Wallin, Celestial cycles. Astronomical concepts of regeneration in the ancient Egyptian coffin texts (Uppsala: University of Uppsala Press, 2002).

67. Goebs, op. cit. (ref. 31).

68. For the White Crown, see Goebs, op. cit. (ref. 31), 154, who argues that: 'when used as an item of insignia with cosmic connotations, the $\underline{h} \underline{d} t$ seems to refer almost exclusively to the luminosity of the moon or stars at night'; as well as: 'in the cosmic context of the early funerary literature, the crown designation $h \underline{d} t$ hence appears to have been chosen specifically to express lunar or stellar light - the latter including the radiance of Horus as the morning (or evening) star'.

69. See Goebs, op. cit. (ref. 31), 204-5, who argues that the Red Crown ought be related to the red light of dawn or sun's disc at sunrise, since 'of the four attestations of $d$ šrt "Red Crown" in the Pyramid Texts, two occur in the so-called Cannibal Spell, the most obvious and revealing spell in relation to blood and slaughter'. However, according to Pyramid Text spelling 243, the White Crown appears after 'devouring' the Red Crown, posing some doubts on this identification ( $\mathrm{R}$. Krauss, private communication). For Krauss, the White Crown would certainly be Venus as 'Morning Star' while he speculates with the idea that the Red Crown would also be a 'stellar entity' and should be interpreted as Venus 'Evening Star'.

70. Although quite speculative and without epigraphic support, it is hypothesized by New York University Egyptologist Patricia Blackwell Gary and ‘Astronomy' senior editor Richard Talcott that the shapes of the ancient Egyptian pyramid and obelisk were derived from natural phenomena associated with the sun. The pyramid and obelisk might have been inspired by previously overlooked astronomical phenomena connected with sunrise and sunset: the zodiacal light and sun pillars respectively. P. Blackwell Gary and R. Talcott, "Stargazing in ancient Egypt", Astronomy, August Vol. (2010), 63-7.

71. See, M. Vázquez and J.M. vaquero, "Aurorae observed at the Canary Islands", Solar Physics 267 (2010), 431-44. For example, in February 1872, a notable aurora was observed in Cairo and as far as Aswan. According to M. Vázquez (private communication) the number of auroras 
(aurorae) increases with the terrestrial latitude. However, low-latitude events have been often reported associated with strong solar storms. For Northern Africa, H.M. Basurah, "Records of aurora in the Islamic chronicles during 9th-16th centuries", Journal of Atmospheric and Solar Terrestrial Physics 1xviii (2006), 937-41, has reported seven events - from Arab sources between the 9 th and the 16th centuries. More recently, M. Vázquez et al. (now in preparation), indicate a minimum of ten observations of aurorae in Northern Africa for the period 1600-2015 A.D. from different western sources. They tend to be clustered in short activity episodes (from weeks to few years) separated by approximately 100 year intervals (a cadence comparable to total solar eclipses). Interestingly, K. McKraken, J. Beer, F. Steinhilber and J. Abreu, "The Heliosphere in time", Space Science Review clxxvi (2013), 59-71, have shown that a maximum of solar activity was possibly present during the epoch of formation of the Egyptian state in the first half of the Third Millennium B.C., in contrast to the most recent centuries when a minimum has been produced. Hence, a larger number of low-latitude aurorae would have been expected when the celestial eschatology of the Pyramid Texts was developed.

72. Goebs, op. cit. (ref. 31), 155.

73. If, instead, dawn is considered as a comprehensive alternative for the crown of the north, the green nature of this might refer to the 'green flash' phenomenon happening immediately before sunrise and sunset, also observable - although for very brief moments - at mid-latitudes clear skies. However, as one of the referees has suggested 'green' can be a usual euphemism for 'red'; see e.g. J.E.Quack, "Mit griiner Tinte rot schreiben”, Göttinger Miszellen clxv (1998), 7-8. The reason would be the general colour symbolism, which is most likely due not to any physical phenomena but perhaps to the warmness of the colour as such.

74. Krauss (private communication) has argued that to identify the White and Red Crowns with the zodiacal light and the aurora borealis [respectively], the related Pyramid and Coffin Texts must be interpreted accordingly. Egyptological multiplicity of approaches is fine, as long as the sources allow it. The fact that the authors are impressed by the zodiacal light and the aurora borealis does not mean that the ancient Egyptians were similarly impressed. The [real] problem is to show from the sources that they were similarly impressed. It is relevant, in this sense, the astonishing apparent silence of Egyptian sources about conspicuous and certainly impressive astronomical phenomena such as eclipses or comets. However, as one of the referees has suggested, this silence could simply be due to chances of preservation. Such information would mostly have been recorded on papyrus in libraries which we know existed but are now lost. Hence, one may not expect everything to have been monumentalized in stone. Interestingly, that the Egyptians must have had many records of eclipses, at least in the Greco-Roman period, is explicitly mentioned by Seneca, Questiones naturales VII, III, 1-2.

75. A fact could certainly be relevant: many 4th and some 5th Dynasty pyramids were cased with pink granite in their lower courses, notably that of Menkaure: see Arnold, op. cit. (ref. 10), 169. A pyramid cased with white limestone in its upper layers and with pink granite in the lower ones would certainly have had an aspect mimicking the double crown of Egypt, the shmty, integrating both the White, $h \underline{d} t$, and Red, $d \check{s} r t$, crowns of Upper and Lower Egypt, respectively. Hence, we may speculate with the idea that Sneferu's symbolism would have been somehow followed by his direct descendants although in a different level. Other aspects of landscape symbolism were also followed by the Pharaohs of later dynasties; see for example G. Magli, "Topography, astronomy and dynastic history in the alignments of the pyramid fields of the Old Kingdom", Mediterranean Archaeology and Archaeometry x (2010), 59-74, and D. Jeffreys, "The topography of Heliopolis and Memphis: some cognitive aspects", in Beitrage zur Kulturgeschichte Ägyptens, $R$. Stadelmann gewidmet, edited by D. Polz (Mainz: Philipp von Zabern, 1998), 63-71.

76. The best orientation accuracy would be achieved one generation later by Sneferu's son Khufu in his pyramid complex at Giza. See E. Nell and C.L. Ruggles, "The orientation of the Giza pyramids and associated structures", Journal for the History of Astronomy xlv (2014), 308-69, for a state-of-the-art approach to this question.

77. Sneferu's Red pyramid superstructure had presumably been started shortly before the year of the 15th occasion (year 19 or 20 of his reign) as shown by mason-marks located in the southwest corner of the monument. Hence, its construction lasted a dozen years or so. See Krauss, op. cit. (ref. 5) and Stadelmann, op. cit. (ref. 14).

78. See M. Shaltout, J. A. Belmonte and M. Fekri, "On the orientation of ancient Egyptian temples: (3) key points in Lower Egypt and Siwa Oasis", Journal for the History of Astronomy xxxviii (2007), Vol. 2, 141-60 (Part I) and Vol. 4, 413-42 (Part II), and G. Magli, "Akhet Khufu: archaeoastronomical hints at a common project of the two main pyramids of Giza, Nexus 
Network Journal xi (2008), 35-50. Also relevant for the inspiration of the idea is R. H. Wilkinson, Symbol and magic in ancient Egypt (London, 1994).

79. And indeed in both cases the orientation errors of the two main pyramids differ from each other by a mere 3', close to the normal resolving power of the human eye, in agreement with a contemporaneous planning. See Table 1 and Nell and Ruggles, op. cit. (ref. 76). However, P. Tallet and G. Marouard, "The harbour of Khufu on the Red Sea coast at Wadi al-Jarf, Egypt", Near Eastern Archaeology 1xxvii (2014), 4-14, have found a papyrus, contemporaneous to Cheops's reign, with a text where $3 h t$ hfw is mentioned with a single determinative of a pyramid (as in later sources). This, according to José Lull (private communication), would be a point against the duality of the complex. Arguably, many pyramid complexes included more than one pyramid (although just a single 'big' one in most cases) and were always named with a single determinative with the notable exception of the - indeed later and not contemporaneous - use of the double determinative in the case of Kha-Sneferu. This question will indeed need further exploration in the future.

80. For Khufu's dates, see Belmonte, op. cit. (ref. 4), Table 8.1 Also relevant would be Tallet and Marouard, op. cit. (ref. 79).

81. The name has also been read as 'Khefren is a great (of heaven)'. For a lengthy discussion on the topic, the name of the second pyramid of Giza included, see Belmonte, Shaltout and Fekri, op. cit. (ref. 42).

82. M. Roaf, "Mesopotamian kings and the built environment", in Experiencing power, generating authority, edited by J.A. Hill, Ph. Jones and A.J. Morales (Philadelphia: University of Pennsylvania Press, 2013), 331-59.

\section{NOTE ON CONTRIBUTORS}

Juan Antonio Belmonte (jba@iac.es) is an astronomer at the Instituto de Astrofísica de Canarias (Tenerife, Spain) where he researches in exoplanets and cultural astronomy. In the last decade he has been investigating the astronomical traditions of ancient civilizations, notably Egypt and the Middle East with several papers and two books on the topic: In search of cosmic order: selected essays on Egyptian archaeoastronomy (SCA, Cairo, 2009), co-edited with Mosalam Shaltout, and Pirámides, templos y estrellas: astronomía y arqueología en el Egipto antiguo (Crítica, Barcelona, 2012). He has acted as section editor and co-author in the monumental Handbook of Archaeoastronomy and Ethnoastronomy recently published (summer 2014) by Springer.

Giulio Magli (giulio.magli@polimi.it) is full professor of Archaeoastronomy at the Faculty of Civil Architecture of the Politecnico of Milan (Italy). His research activity developed first in theoretical astrophysics, but for many years he has concentrated on archaeoastronomy, with a special interest in the relationship between architecture, landscape and astronomy. On this subject he has authored several papers and the books Mysteries and Discoveries of Archaeoastronomy (Springer, Heidelberg/New York, 2009) and Architecture, astronomy and sacred landscape in ancient Egypt (CUP, Cambridge, 2013).

TABLE 1. Technical characteristics of the two gigantic pyramids of Sneferu at Dahshur (latitude of $29^{\circ}$ $471 / 2$ '). Each pyramid is identified by its name in hieroglyphs and its common name. The table presents the base and height (in metres), the azimuth, in minutes of arc, the slope (in degrees), and corresponding tangent [* and ** for the lower and upper sections of the southern Bent Pyramid, respectively; and *** for the pyramidion of the northern Red Pyramid; the pyramid of Sneferu at Meidum had a slope of $51^{\circ} 50^{\prime}$ $35^{\prime \prime}$, similar to the Great Pyramid (51 ${ }^{\circ} 50^{\prime} 40^{\prime}$ ), for comparison], ${ }^{51}$ the declination in the first vertical at the corresponding slope, the slopes of the different access corridors (SoC) and, finally, the corresponding sky declination. See the text for an analysis of these data and for further discussions.

\begin{tabular}{|c|c|c|c|c|c|c|c|c|c|}
\hline Pyramid name & Nickname & b (m) & h (m) & Az. & Slope & Tangent & $\delta 1^{\text {st }} \mathbf{V}$ & SoC & $\delta \mathrm{C}$ \\
\hline\|\|$_{\theta}^{*}-\Delta \Delta$ & Bent Pyramid & 188 & 105 & $-12^{\prime}$ & $\begin{array}{l}54^{\circ} 28^{\prime} * \\
43^{\circ} 23^{\prime} * *\end{array}$ & $\begin{array}{l}7 / 5 \\
20 / 21\end{array}$ & $\begin{array}{l}23^{\circ} 56^{\prime} \\
20^{\circ} 4^{\prime}\end{array}$ & $\begin{array}{l}\text { N } 27^{\circ} 30^{\prime} \\
\text { W } 30^{\circ} \text { 9' } \\
\text { W } 24^{\circ} 17^{\prime}\end{array}$ & $\begin{array}{l}87^{3} 4^{\circ} \\
141^{1}{ }^{\circ} \\
11^{\circ}\end{array}$ \\
\hline$\|_{\theta}^{+\infty} \infty a \Delta$ & Red Pyramid & 220 & 105 & $-9^{\prime}$ & $\begin{array}{l}43^{\circ} 40^{\prime} \\
54^{\circ} 30^{\prime} * * *\end{array}$ & $\begin{array}{l}20 / 21 \\
7 / 5\end{array}$ & $\begin{array}{l}20^{\circ} 8^{\prime} \\
23^{\circ} 55^{\prime}\end{array}$ & $27^{\circ} 56^{\prime}$ & $88^{1 / 4^{\circ}}$ \\
\hline
\end{tabular}




\section{FIGURES AND CAPTIONS}

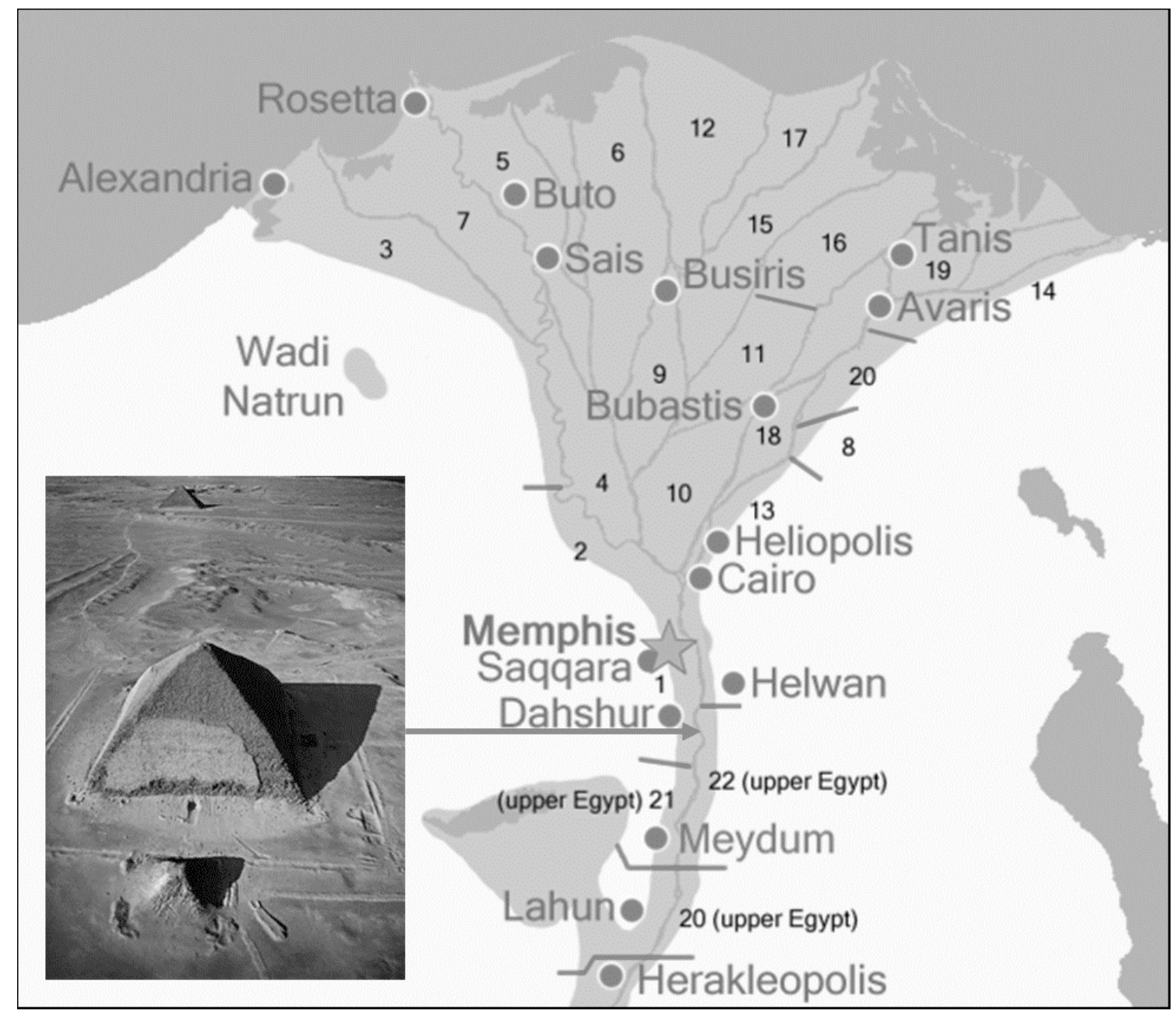

FIG. 1. Location of Dahshur precisely at the frontier between Upper (South) Egypt and Lower (North) Egypt, actually in front of the traditional frontier between nome 22 of Upper Egypt and nome 13 of Lower Egypt. The most outstanding and the first built monuments on site are Sneferu's Bent - and its satellite (close-up) and Red (in the foreground) Pyramids. Diagram of the authors with images courtesy of Google Earth. 

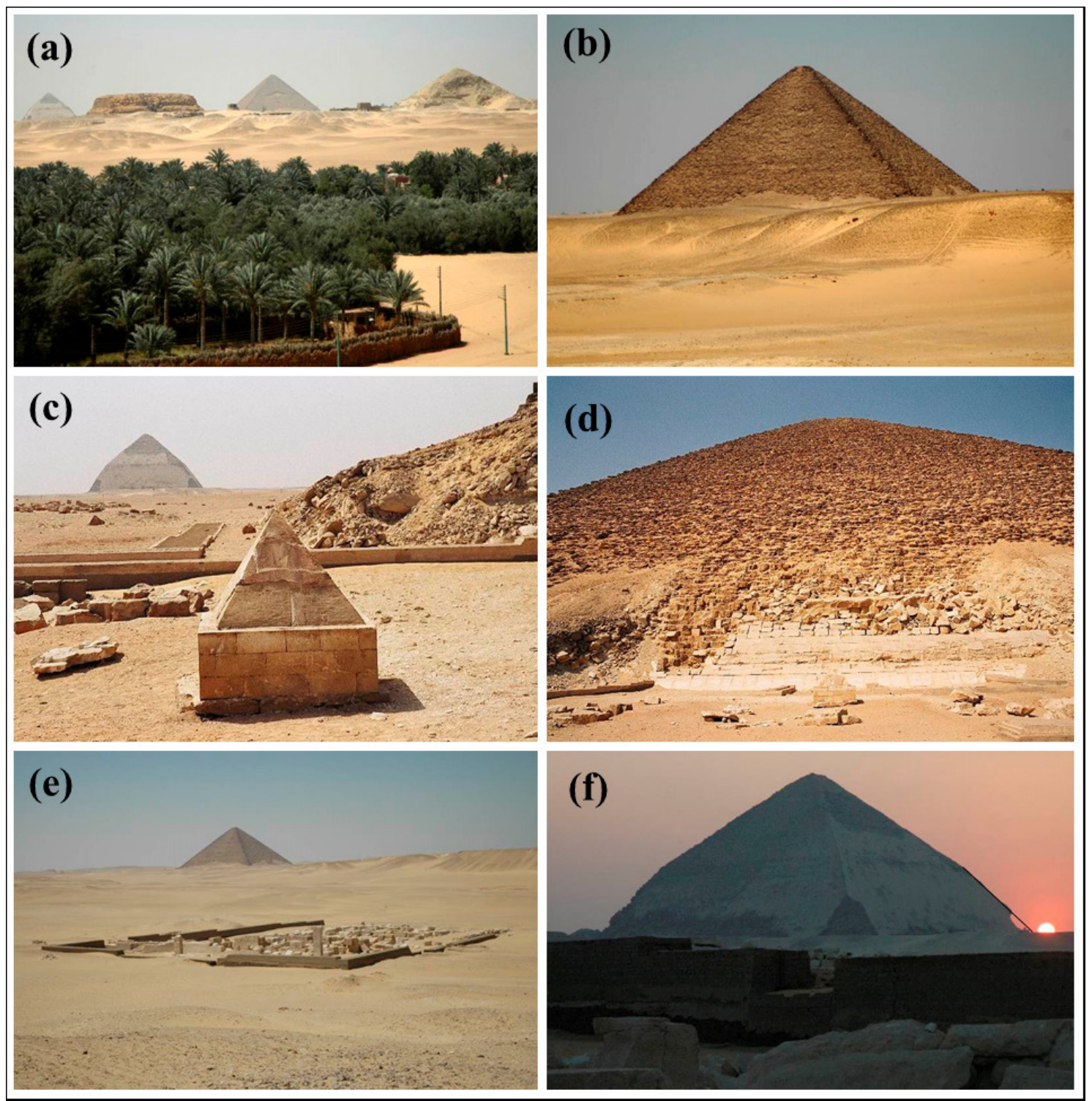

FIG. 2. Different aspects of the architecture and landscape of the pyramids of Sneferu at Dahshur: (a) the pyramids as seen from Djedkare Isesi's funerary complex at Saqqara, notice Sneferu's pyramids nestling the mastaba of king Shepsheskaf; (b) the Red Pyramid with its typical reddish (actually brownish) aspect, much darker than the neighbouring landscape; (c) the reconstructed pyramidion of the Red Pyramid with the Bent pyramid in the foreground; (d) part of the 'surviving' limestone casing of the Red Pyramid in the sector limiting the associated funerary temple; (e) the 'Valley' temple of the Bent Pyramid with the Red one in the distance; and (f) winter solstice sunset in the northwest corner of the Bent pyramid as observed from Sneferu's Valley temple. Images by the authors. 


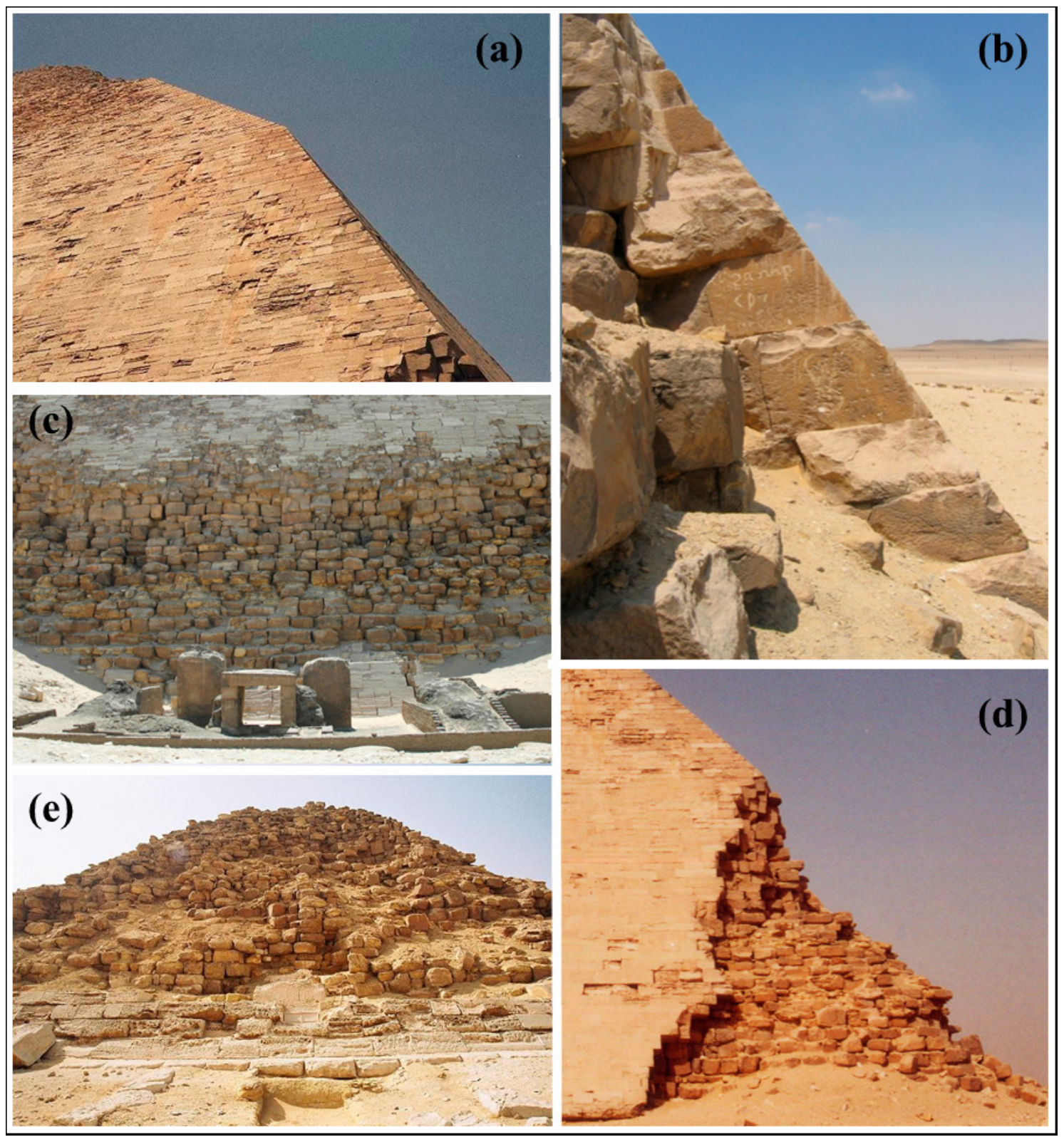

FIG. 3. Different views of the Bent pyramid of Sneferu showing its peculiarities: (a) the smooth change from the $5412^{\circ}$ to the $4312^{\circ}$ slope; (b) the fine limestone incline stones of the casing contrasts with the rough stone horizontal layers of the internal core; (c) the funerary temple of the king in the eastern side of the pyramid showing several layers of horizontal stones of the filling; (d) only in the corners of the pyramid were stone-robbers successful, thereby providing us with a view of the construction technique in horizontal layers, exactly the same as that of the satellite pyramid (e) - its northern face with the entrance close to ground level is visible. Images by the authors. 


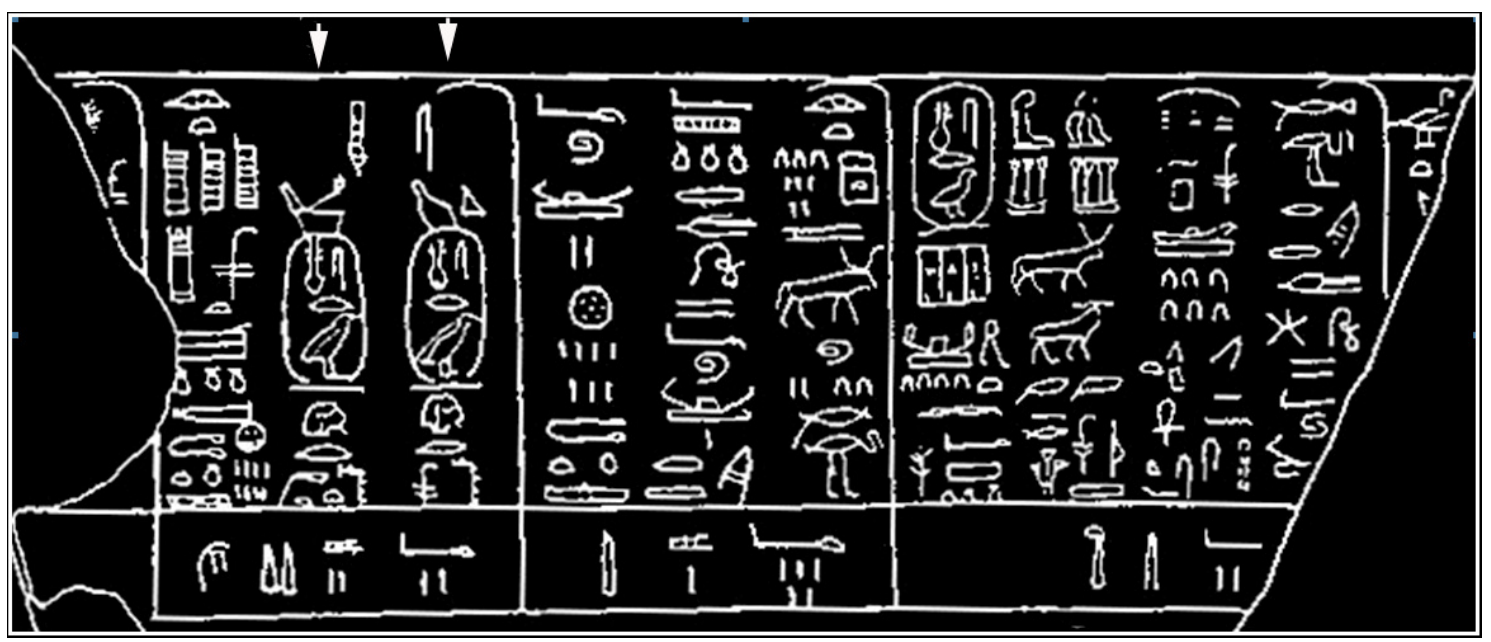

FIG. 4. The corresponding entries for three years (from right to left, year before the 7 th occasion and the years of the 7th and 8th occasion, respectively; presumably years 8/9, 9/10 and 10/11) of the reign of Sneferu in the Annals of the King in the Palermo Stone. The (start of the) construction of the two pyramids at Dahshur might be mentioned in the latter register (arrow marks). Plot by the authors, adapted from a photograph by Margarita Sanz de Lara taken courtesy of the Archaeological Museum of Palermo.

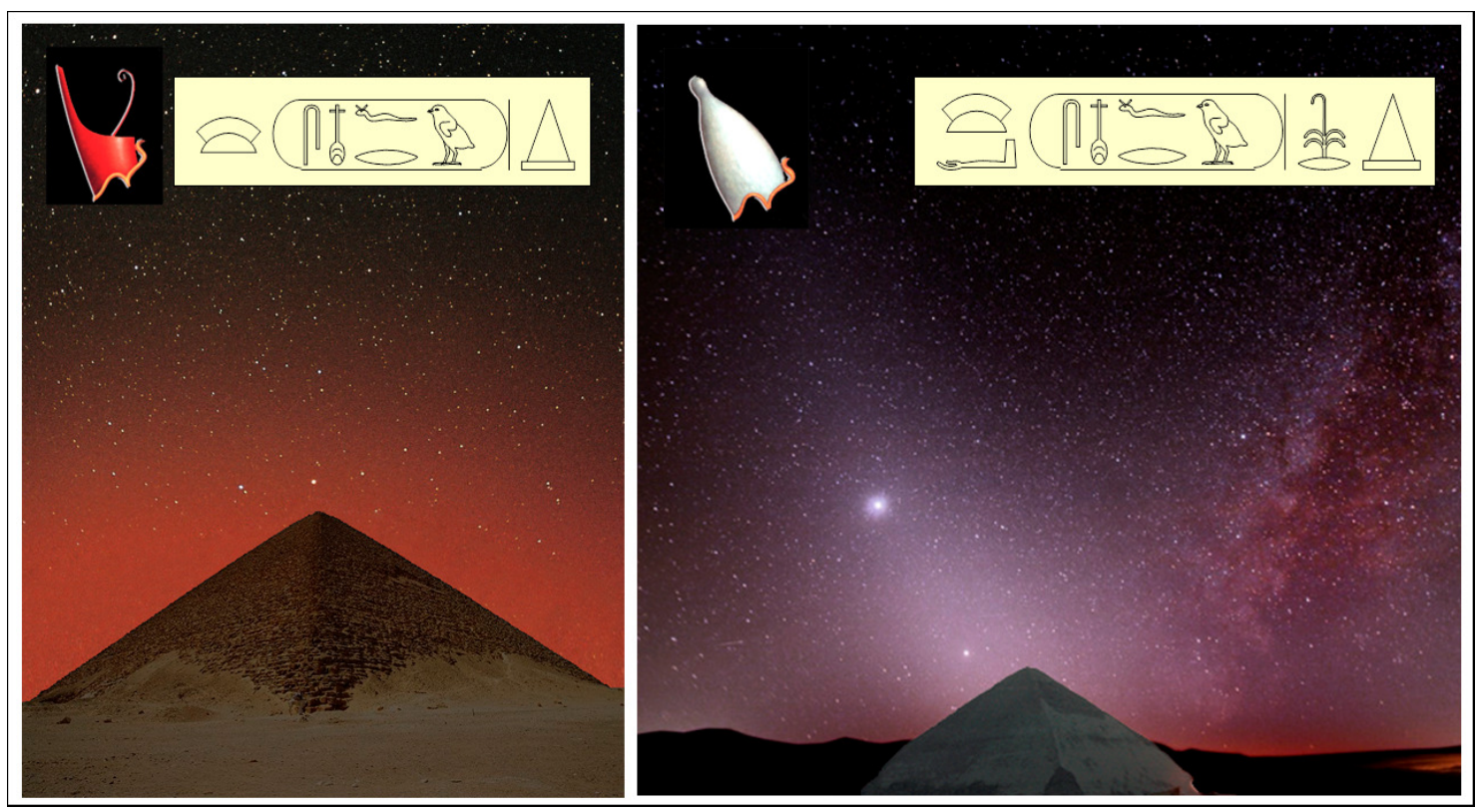

FIG. 5. Astronomy, architecture and symbolism at Dahshur: the Red (left) and Bent (right) pyramids as symbolic representation of the Red and White crowns, respectively, as petrified counterparts of relevant respective reddish and whitish celestial phenomena such as the aurora borealis or the zodiacal light (plus Venus). See the text for further details. Diagram by the authors courtesy of the Multimedia Service of the IAC, in images courtesy of Graham Parkin and Daniel López, respectively (see Fig. 8). 


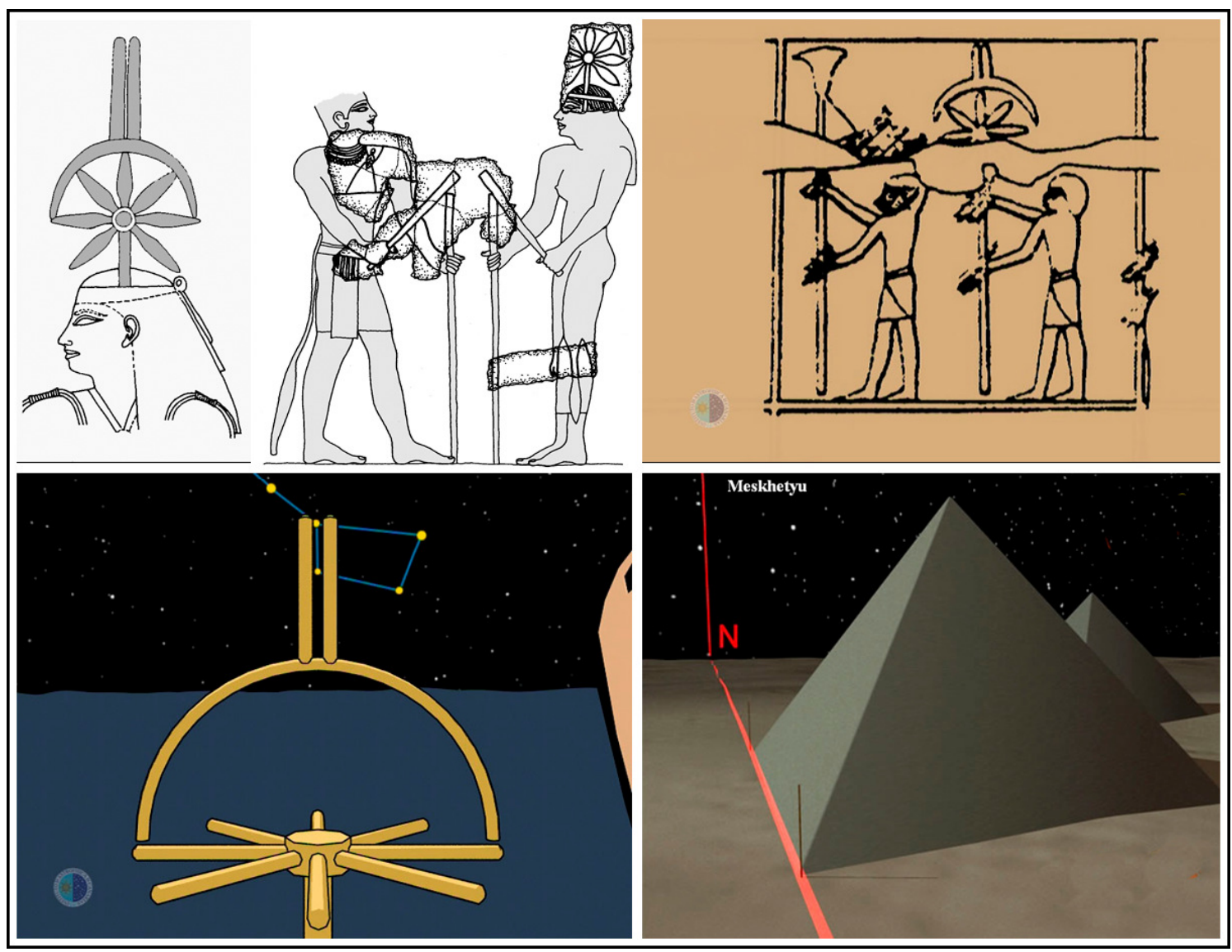

FIG. 6. Diagram showing different aspects of the alignment process of the pyramids related to the 'stretching of the cord' ceremony according to the first author's hypothesis, involving the goddess Seshat's sign. ${ }^{43}$ One of the first representations of the ceremony was found at the Valley temple of Sneferu at Dahshur (upper left). The 4th Dynasty pyramids, including those at Dahshur, could have been orientated according to the simultaneous meridian transit at lower culmination of a couple of stars of the Egyptian imperishable constellation Meskhetyu. Diagram by Juan Antonio Belmonte, adapted from images from Belmonte (2012). ${ }^{4}$ 


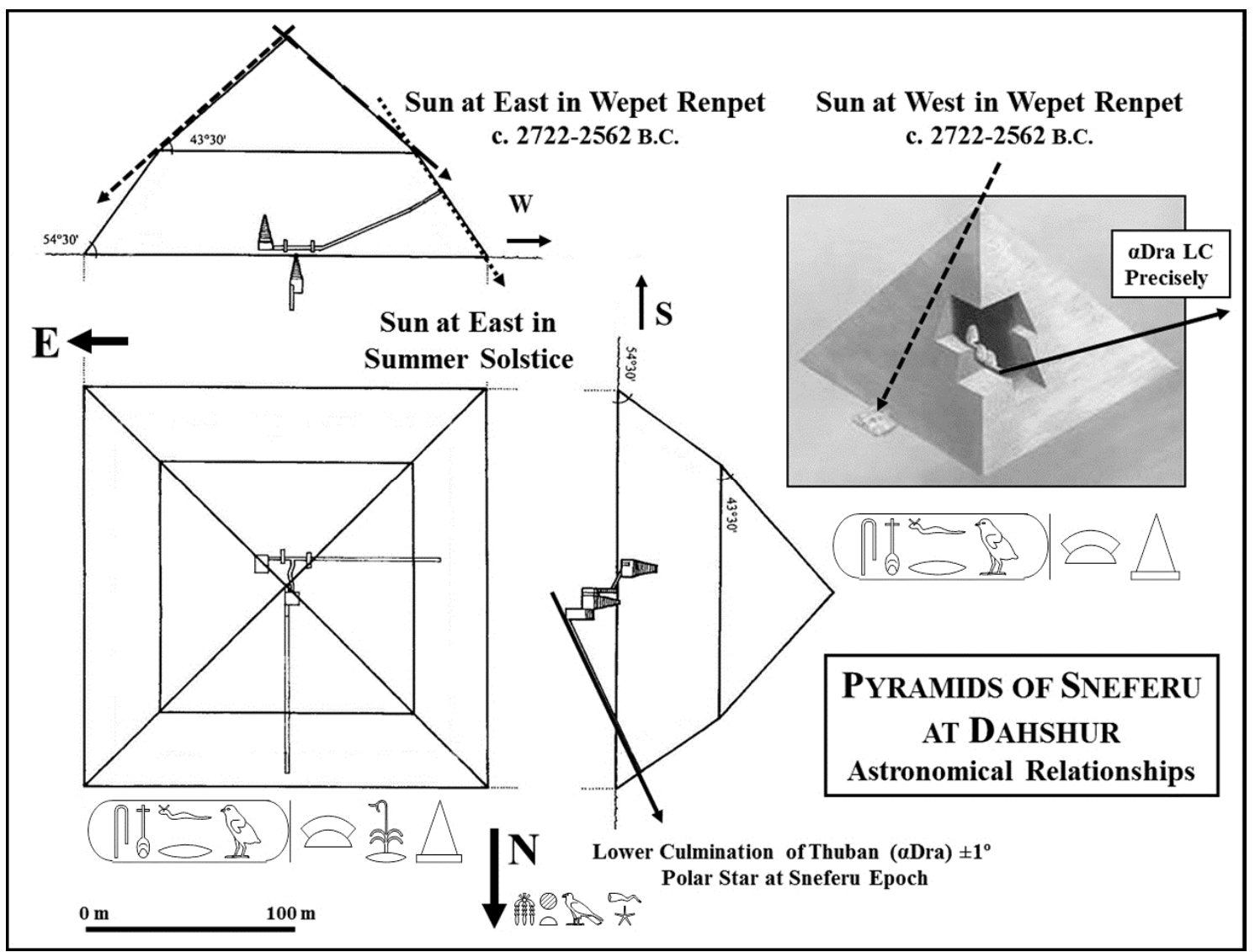

FIG. 7. Astronomical relationships at the pyramids of Sneferu in Dahshur. Both pyramids are well orientated towards north (see text) and the slope of the corresponding access corridors apparently points them to the lower culmination of Thuban, the pole star during the Old Kingdom. The slopes of the two pyramids might be related to a couple of important marks of the Egyptian time-keeping system, the summer solstice and Wepet Renpet (New Year's Eve). See the text for further discussion. 


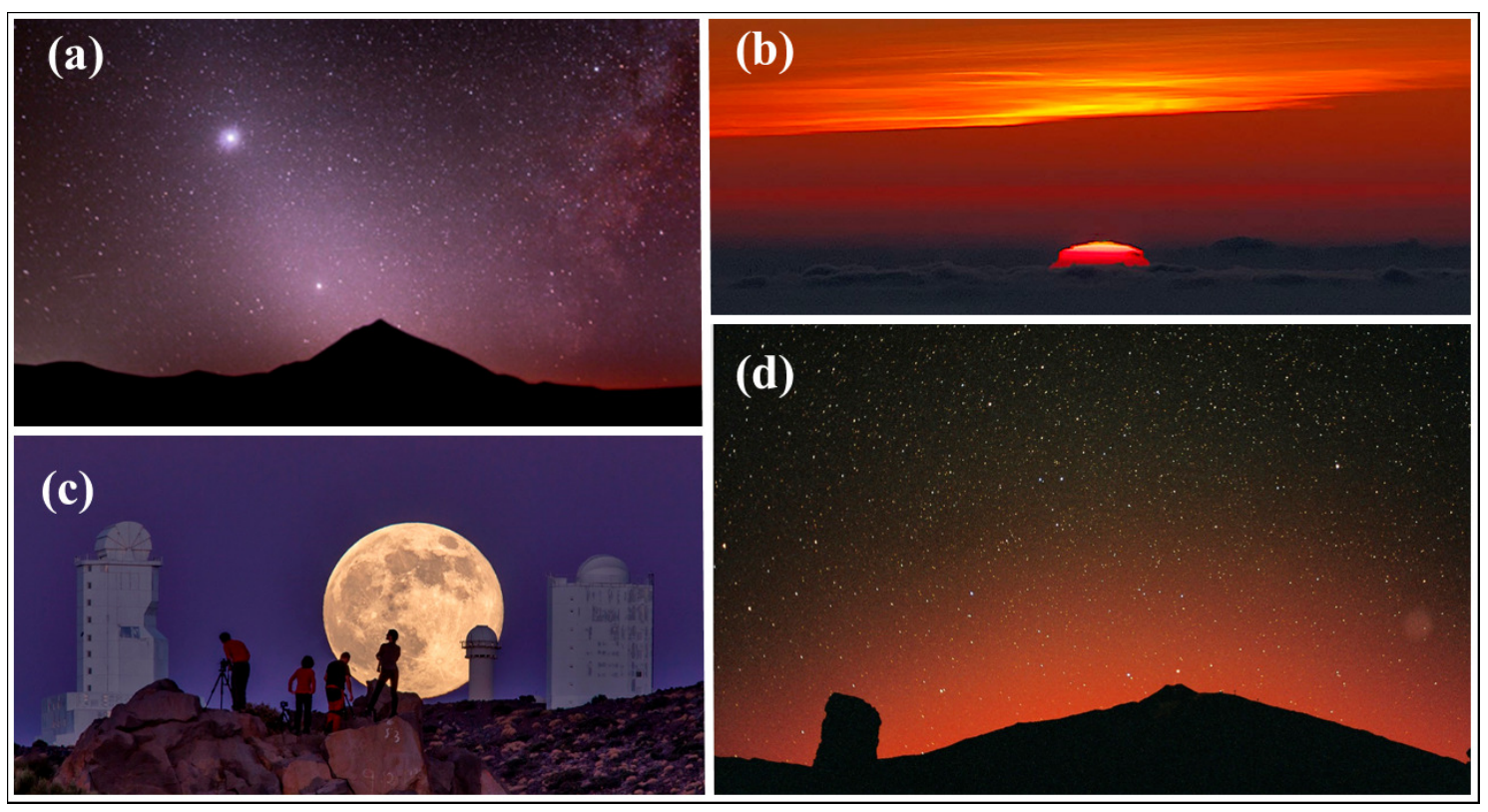

FIG. 8. Celestial lights as observed from the Canary Islands (average latitude similar to the Egyptian pyramid fields) that could be connected with certain aspects of the divinized king in the Pyramid Texts, notably with the Red and White crowns: (a) the planet Venus in the glare of the zodiacal light above Teide volcano on the island of Tenerife; (b) the red and orange light of dawn at sunrise as observed from Teide Observatory; (c) the bright Moon on the horizon contrasting with the domes of Teide Observatory; and (d) the reddish light of an aurora borealis observed on 2003 November 20 from Teide National Park - note the constellation Ursa Minor above the peak. See the text for further details. Photographs courtesy of Daniel López and IAC Archive (a, b and c) and Graham Parkin (d). 


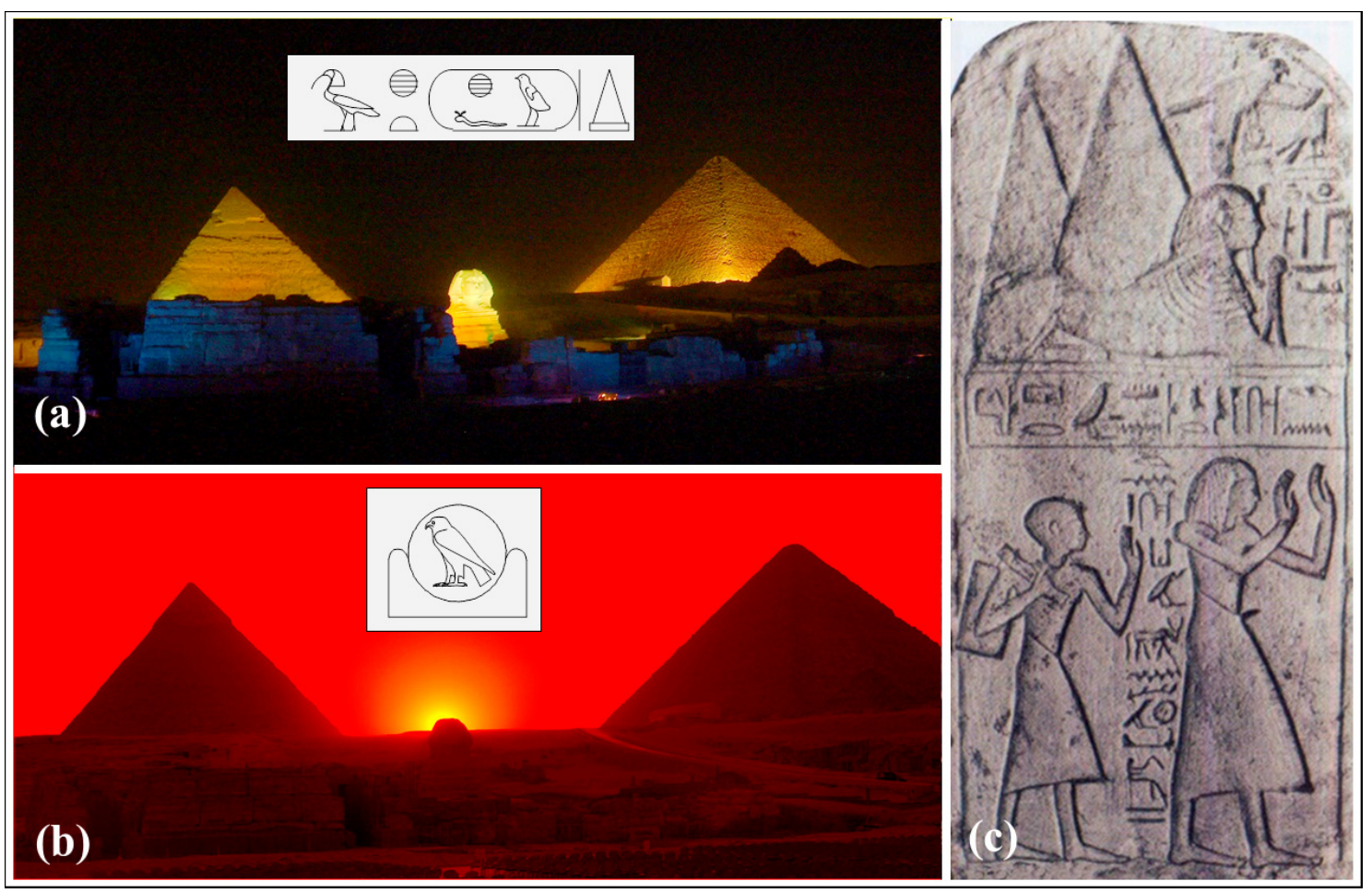

FIG. 9. Architecture and astral symbolism at Giza as initially recreated in the Old Kingdom (a) with the hypothetical two-pyramid plus Sphinx project of Cheops, or 3ht hffw, 'Khufu's Horizon', and (b) as a symbolic reinterpretation as the god Hor-em-akhet, 'Horus at the Horizon', during the New Kingdom. Finally, (c) Stela iii2.43 of Mentuher and Kamutnakht (18th Dynasty) clearly illustrates this close relationship. Diagram by the authors, with photographs courtesy of Margarita Sanz de Lara (a) and Juan A. Belmonte (b and c), (c) courtesy of the Egyptian Museum in Cairo. 